\title{
ESTUDIO SOBRE TUTELA DECLARATIVA CIVIL ESPECIAL EN EL SISTEMA PROCESAL ESPAÑOL. ¿NECESIDAD O IMPERICIA LEGISLATIVA?
}

JOSÉ MARÍA ROCA M.

\section{Resumen}

Este trabajo reflexiona acerca de la existencia del gran número de instrumentos de tutela procesal civil especial en el derecho español, debatiendo si dicha política se justifica, o si, por el contrario, se trata de una exageración fruto de la incapacidad del legislador de abordar de manera coherente y sistemática este ámbito.

\section{Palabras clave:}

Tutela declarativa especial, sistema procesal español.

\begin{abstract}
This work reflects on the huge disposal of instruments of special civil procedures in spanish law, debating if this politic is justified or it is an exaggeration whose origin comes form de legislator icapacity to handle coherently and sytamitacly this subject
\end{abstract}

\section{Key words:}

Special civil procedures, spanish procedural law.

\section{Introducción}

Desde un punto de vista teórico podría existir un proceso civil con una única tramitación procedimental; sin embargo, históricamente no ha sido

1 Profesor Titular de Derecho Procesal Universidad de Oviedo. joseroca@uniovi.es. 
así ni para la tutela ordinaria ni para la tutela especial. ${ }^{2}$ La tutela procesal ordinaria se identifica con la prevista con carácter general, para cualquier tipo de pretensión, sea cual sea su naturaleza, y sin particularidades en su tramitación; ${ }^{3}$ por el contrario, la tutela especial viene referida a un ámbito concreto, generalmente por la materia, incluyendo particularidades procedimentales. La existencia de tales especialidades procedimentales, en mayor o menor medida, viene siendo algo habitual en el Sistema Procesal español; hace ya muchos años que Serra Domínguez alertaba sobre la necesidad de simplificar el laberíntico panorama de procedimientos especiales; la situación, a pesar del esfuerzo llevado a cabo en la LEC, no parece haber mejorado significativamente.

La LEC apostó de manera decidida por la simplificación de los procesos ordinarios, reduciendo su número de cuatro a dos, ${ }^{4} \mathrm{e}$ instaurando la oralidad, la inmediación y la concentración. Se trata de un modelo consolidado y suficientemente probado, como lo muestra el hecho de que sea el propuesto por el Código Procesal Civil Modelo para Iberoamérica, ${ }^{5}$ que ha servido de

2 "No existe una razón única que justifique la proliferación de juicios especiales: la frecuencia o complejidad de algunas cuestiones, las necesidades de una resolución rápida, las particularidades que impone un determinado objeto litigioso, etc., son algunas de las motivaciones que se esgrimen como justificación de la creación de nuevos juicios especiales. Lo sarcástico de tal orientación es que con la especialización casi nunca se consiguen los objetivos de claridad y rapidez presupuestados" (RAMOS MÉNDEZ, F.: Enjuiciamiento Civil. Cómo gestinar los litigios civiles, T. II. Atelier, Barcelona. 2008. Págs. 1541 y 1542.

3 Guasp habla de tipos de proceso de cognición "pensados para hipótesis generales e indeterminadas o para hipótesis singulares y concretas" (GUASP DELGADO, J.: Derecho Procesal Civil, Tomo segundo, Parte especial, $3^{\mathrm{a}}$ ed. Instituto de Estudios Políticos, Madrid, 1968. Pág.404).

4 Con ello se alcanzó una aspiración de la doctrina procesal, reiteradamente propuesta. Como ejemplo, ALMAGRO NOSETE, J.: Instituciones de Derecho Procesal. Proceso Civil, (Tomé Paule, J. Coaut.), 2a ed. Editorial Trivium, S.A., Madrid, 1994. Pág. 439: "una reforma seria -con asesoramientos técnicos de calidad- de la LEC ... para por una reducción, posiblemente a dos, de aquellos tipos: uno de mayor solemnidad sustitutivo de los juicios de mayor y menor cuantía y otro que reemplace a los denominados ahora de «cognición y verbal»".

5 Del Código Procesal Civil Modelo para Iberoamérica he escrito que "de manera necesariamente sintética se pueden recordar sus principios estructurales: orgánicamente se configura una fase de instancia ante un órgano unipersonal y una fase de revisión plena ante un órgano colegiado; funcionalmente se potencian las facultades del juzgador, aumentando su poder de dirección y de control; formalmente la oralidad predomina sobre la escritura; procedimentalmente se simplifican los instrumentos de tutela sobre la base de un tipo general estructurado en dos audiencias, la primera saneadora y delimitadora y la segunda de juicio oral (con una modalidad acelerada) y la especialidad que supone la técnica monitoria" (Roca Martínez, J.M.: "El Código Orgánico General de Procesos del Ecuador". En: GARCÍA 
inspiración a la mayoría de países de su área de influencia. En paralelo a esta transformación radical del modelo de enjuiciamiento civil, la justificación de las especialidades va perdiendo fuerza; como explica Asencio Mellado, "no puede entenderse la nueva LEC si no se atiende o se tiene en cuenta el dato de la radical transformación operada en la norma procesal civil en orden a la regulación de los procedimientos declarativos ordinarios y a los principios que los informan ". ${ }^{6} \mathrm{Si}$ con el trasnochado modelo de la LEC 1881, anclado en la escritura, la dispersión y la mediación, tenía cierta justificación el fenómeno de huida explicado por Montero Aroca, ${ }^{7}$ con la sustancial transformación operada por la LEC, los argumentos con que se sostenía desaparecen o, al menos, se debilitan.

Lo cierto es que la LEC trató de mejorar la sistemática y de reducir las especialidades. Respecto a los procesos especiales, su exposición de motivos afirma tajantemente que se establecen los imprescindibles: (a) en asuntos de capacidad, filiación y matrimoniales, (b) relativos a la división judicial de patrimonios y (c) los procesos monitorio y cambiario. En relación a los tradicionalmente denominados procedimientos ordinarios con especialidades o simplemente procedimientos especiales, la LEC aspiraba a terminar con la práctica tradicional de incorporar disposiciones procesales en las leyes especiales, pero solo ha sido capaz de hacerlo parcial y formalmente; de manera parcial porque subsisten especialidades fuera de la LEC, tanto anteriores a ella (Transporte Terrestre), como posteriores (Marcas, Diseño Industrial, Defensa de la Competencia, Partidos Políticos), incluso, en ocasiones, la incorporación parcial se produce respecto a la misma ley, manteniendo especialidades en la legislación sustantiva (Competencia Desleal, Patentes, Propiedad Intelectual); de manera formal porque en la mayoría de los casos el cambio es solo de lugar, limitándose a incorporar las disposiciones de las leyes especiales. Se ha llevado a cabo un importante esfuerzo simplificador en materia de prueba (214.4), diligencias preliminares (256), documentos que han de acompañarse a la demanda

FALCONÍ, R. y PÉREZ-CRUZ MARTÍN, A.J. (dirs. y coords.): Código Orgánico General de Procesos comentado, VVAA, T.I. Latitud Cero editores, Quito, 2018. Pág. 65.

6 Asencio Mellado, J.M .: Derecho Procesal Civil, $3^{\text {a }}$ ed. Tirant lo Blanc, Valencia, 2015. Pág. 503.

$7 \quad$ El fenómeno tuvo como resultado una "verdadera proliferación procedimental", que lejos de obedecer a justificaciones de técnica procesal, respondió "en la mayor parte de los casos, a la existencia de fuerzas sociales capaces de lograr del legislador la creación de tutelas propias frente a la tutela normal que se prestaba por los procesos ordinarios" (MONTERO AROCA, J.: Derecho Jurisdiccional II, Proceso Civil, VVAA, $26^{\mathrm{a}}$ ed. Tirant lo Blanch, Valencia, 2018, biblioteca Tirant on line. Pág. 50). 
(266), regulación del juicio verbal (demanda -437, 439-, tramitación -439, 440, 441-) o medidas cautelares (727). Aun así, aparte de los procesos especiales del Libro IV, lo cierto es que el esfuerzo simplificador no ha impedido que la doctrina insista en ver y estudiar instrumentos de tutela procesal especial, bajo diversas denominaciones (procedimientos ordinarios con especialidades, especialidades procedimentales o simplemente procedimientos especiales). ${ }^{8}$ No cabe obviar, además, por un lado, que las sucesivas reformas de la LEC han ido ampliando las especialidades e introduciendo nuevas figuras, y por otro, que algunas leyes sustantivas han roto con la aspiración originaria de la LEC y han regulado cuestiones de naturaleza procesal fuera de ésta.

Sin cuestionar la consideración de las especialidades procesales como opción de política legislativa, reflexiono en este trabajo sobre la necesidad de disponer de tantos instrumentos de tutela procesal civil especial o si, por el contrario, se trata de una exageración fruto de la incapacidad del legislador de abordar de manera coherente y sistemática la cuestión.

\section{La justificación de la tutela declarativa especial.}

Puso de manifiesto Guasp que "si se indaga el porqué fundamental de la existencia de un proceso especial, se observa en primer término que ese porqué es susceptible de obedecer a dos series de razones distintas entre las cuales agotan todas las posibilidades de tal causación". ${ }^{9}$ Más de medio siglo después, sus palabras siguen estando plenamente vigentes y del análisis de los instrumentos de tutela declarativa especial existentes en nuestro Sistema Procesal, no cabe llegar a ninguna otra conclusión: las especialidades se deben a una razón de derecho material o a una preocupación concreta de orden procesal; si acaso, podría pensarse en especialidades que obedecen a ocurrencias, más o menos oportunistas, del político de turno metido a legislador ocasional.

La interrelación entre el derecho sustantivo y el procesal es una realidad incuestionable; las particularidades sustantivas tienen trascendencia procesal, si bien puede ser de muy diversa importancia y no siempre

$8 \quad$ Cualquier intento de sistematización constituye un esfuerzo baldío, condenado de antemano al fracaso. Ya Guasp puso de manifiesto tales dificultades: "nada más difícil, por no decir imposible, que establecer, dentro de un cierto derecho positivo, una tipología lógicamente satisfactoria y prácticamente exhaustiva de los procesos especiales" (GUASP DELGADO, Derecho Procesal Civil, ob. cit. Pág. 408. 
justifica la articulación de una tutela procesal especial. El principal criterio utilizado como justificación de la regulación de instrumentos de tutela procesal declarativa especial o de especialidades en los instrumentos de tutela procesal declarativa ordinaria no cabe duda que era y sigue siendo la materia. Así sucede con la mayoría de los procesos especiales (a excepción del monitorio), en los que la importancia de la materia es destacada por la LEC (EM XIX) como razón justificadora para regular "los procesos especiales imprescindibles" en su Libro IV, a los que atribuye "inequívocas e indiscutibles particularidades". Como tales considera los litigios en asuntos de capacidad, filiación y matrimoniales (debe añadirse menores), los relativos a la división judicial de patrimonios y los dos "más novedosos", el monitorio y el cambiario (sí es novedoso el monitorio, pero del cambiario lo novedoso es su regulación).

Lo mismo ocurre con los procedimientos especiales. El legislador ha venido mostrando una exagerada tentación hacia la proliferación de preceptos procesales en cuantas normas sustantivas iba aprobando (arrendamientos, sociedades, patentes, propiedad horizontal, etc.), generando un sinfín de tramitaciones, en general, tan injustificadas como variopintas. La acertada explicación que propone Ramos Méndez es harto elocuente: "La vocación legislativa por procesalizar casi todo deriva de una redical posición dualista de las relaciones entre derecho y juicio y por una desconfianza innata hacia el propio sistema procesal. Lo primero se expica por la tradición: el ordenamiento procesal sería sólo el hacha de guerra del derecho sustantivo. Regulada una relación jurídica ex novo, le parece natural al legislador dotarl $a$ de armas para la guerra de las galaxias. Lo segundo es menos justificable, pues buena parte de la sensación deriva de la incuria del propio legislador". ${ }^{10}$

Y me he referido a la loable intención simplificadora de la LEC, sin embargo, la obsesiva tentación lejos de desaparecer, continúa presente y hasta se podría pensar que de manera creciente. La materia sigue siendo, también aquí, la razón justificadora de las especialidades. Cuestiones como la legitimación, la exigencia de realizar actuaciones previas, la necesidad de acompañar determinados documentos con la demanda o particularidades en las diligencias preliminares, en las medidas cautelares, en materia probatoria, en la sentencia o en la ejecución provisional, son algunas de las especialidades habituales. 
Pero no solo la materia justifica la existencia de tutela declarativa especial; también se sostiene en razones estrictamente jurídico procesales. Ejemplo de ello, entre los procesos especiales, es el monitorio, caracterizado por la inversión de la iniciativa del contradictorio y, entre los procedimientos especiales, los sumarios, caracterizados por la limitación del objeto, de las posibilidades de alegación y de la cosa juzgada.

\section{Procesos especiales.}

\section{Procesos no dispositivos.}

En el primer bloque (Título I del Libro IV) encontramos materias muy heterogéneas, pero que tienen en común la limitación de la autonomía de la voluntad; ${ }^{11}$ el derecho sustantivo es, en estos supuestos, de aplicación imperativa o de ius cogens y ello trasciende al derecho procesal determinando la vigencia, en mayor o menor medida, de los principios de necesidad y oficialidad, en detrimento de oportunidad y dispositivo; como consecuencia, no es posible la aplicación extrajudicial del derecho (el proceso es el único instrumento para ello: necesidad) y se limitan las facultades de disposición sobre el objeto del mismo (no cabe renuncia, transacción, desistimiento, etc.: oficialidad). Sobre la necesidad de regular estos procesos especiales no las debía tener todas consigo el legislador cuando en la propia exposición de motivos se plantea dudas desde el punto de vista sistemático ${ }^{12}$; dudas que Gimeno extiende a toda la regulación de los procesos y procedimientos especiales. ${ }^{13}$

11 "Revisten en mayor o menor medida un interés público" (Díez-Picazo Giménez, I.: Derecho Procesal Civil. Ejecución forzosa. Procesos especiales, $3^{\mathrm{a}}$ ed.: De la Oliva Santos, A. y Vega Torres, J. (coaut.). Editorial Universitaria Ramón Areces, Madrid, 2005. Pág. 416. 12 "Destacables resultan las medidas cautelares específicas que se prevén y que, en aras de las ventajas prácticas de una regulación procesal agrupada y completa sobre estas materias, se insertan en estos procesos especiales, en vez de llevarlas, conforme a criterios sistemáticos tal vez teóricamente más perfectos, a la regulación general de tales medidas" (EM XIX LEC).

13 GIMENO SENDRA, V.: Derecho Procesal Civil II. Los procesos especiales, $3^{\mathrm{a}}$ ed. Colex, Coruña, 2010. Pág. 241. 
Estos procedimientos se enumeran (aunque de forma incompleta) en el artículo 748 y se refieren a la capacidad, ${ }^{14}$ a la filiación, ${ }^{15}$ al matrimonio ${ }^{16} \mathrm{y}$ a algunos aspectos sobre menores. ${ }^{17}$

Como características comunes se pueden destacar las siguientes:

Indisponibilidad del objeto del proceso (751). No surte efecto la renuncia, el allanamiento, ni la transacción y el desistimiento requiere la conformidad del MF, excepto en los procesos de declaración de prodigalidad, así como de filiación, paternidad y maternidad si no hay menores, incapaces o ausentes; en los de nulidad matrimonial por minoría de edad instada al alcanzar la mayoría y por error, coacción o miedo grave; en los procesos de separación y divorcio.

Especialidades en relación a las partes. El MF es siempre parte en procesos sobre capacidad, nulidad matrimonial, sustracción internacional de menores y filiación; también es parte cuando alguno de los interesados sea menor, incapacitado o esté en situación de ausencia legal (749). Se requiere representación y defensa y en el divorcio de mutuo acuerdo puede ser única para ambas partes (750).

Especialidades en materia de prueba (752). Menor rigor de la preclusión y flexibilidad en las alegaciones y su aportación al proceso; aumento de las facultades del tribunal (puede acordar la práctica de pruebas de oficio); limitación a la eficacia de la admisión de hechos (no vincula al tribunal) y al silencio o respuestas evasivas; no se aplican las reglas sobre prueba legal.

Procedimiento (753). La tramitación se sustanciará por el juicio verbal con contestación escrita y conclusiones orales, teniendo carácter preferente si alguno de los interesados es menor, incapacitado o está en situación de ausencia legal. Los tribunales pueden decidir la celebración de las sesiones

14 Declaración de incapacidad, reintegración de la capacidad, la modificación de la extensión y los límites de la declaración de incapacidad, la declaración de prodigalidad y el internamiento no voluntario por razón de trastorno psíquico

15 Reclamación de la filiación impugnación de la misma.

16 Procedimiento contencioso, de mutuo acuerdo, medidas provisionales, medidas definitivas, a los que hay que añadir el reconocimiento civil de resoluciones eclesiásticas.

17 Sobre guarda y custodia y sobre alimentos, relativos a la obtención de autorizaciones judiciales, sobre restitución o retorno y declaración de ilicitud del traslado o retención en supuestos de sustracción internacional de menores, para oponerse a resoluciones administrativas, para solicitar prestar el necesario consentimiento en la adopción y para oponerse a las resoluciones y actos de la Dirección General de los Registros y del Notariado en materia de Registro Civil. 
a puerta cerrada (exclusión de la publicidad) y el LAJ puede acordar de oficio la comunicación de la sentencia a los Registros Civiles.

Quizá sea este grupo de procesos especiales el que más justificada tenga su existencia. Conviene, en todo caso, hacer algunas reflexiones sobre estas especialidades. Comenzando por el procedimiento (verbal con contestación escrita), ha de tenerse en cuenta que la especialidad ha desaparecido con la reforma del año 2015 (artículo Único.50 Ley 42/2015, de 5 de octubre) que introdujo la contestación escrita en el juicio verbal; la flexibilización de la regulación de la disolución del matrimonio deja sin aplicación muchos artículos; la mayoría de las especialidades solo son aplicables cuando resultan afectados menores o personas discapacitadas, e incluso en estos casos se favorece la mediación (778 quinquies.12). ${ }^{18}$

\section{La división judicial de patrimonios}

El Título II del Libro IV regula la División Judicial de Patrimonios, distinguiendo dos procesos especiales: la división de la herencia (782805) y la liquidación del régimen económico matrimonial (806-811). Se trata de procesos a los puede acudirse a falta de acuerdo de las partes en cuanto a la forma de reparto de los bienes que integran el patrimonio; de hecho, la propia LEC trata de favorecer el acuerdo entre los afectados $(787.4,806,810.3)$. Ambos se caracterizan por afectar a la totalidad de bienes que integran el patrimonio, ya sea la masa hereditaria o a la masa común de bienes y derechos sujetos a cargas y obligaciones consecuencia de un matrimonio. Así pues, la existencia de una pluralidad de titulares sobre esa masa patrimonial común, la situación de indivisión y la falta de acuerdo entre los titulares son las razones utilizadas para justificar la intervención judicial para llevar a cabo la división, desarrollando una doble función de supervisión y de decisión. Las especialidades se centran en las actuaciones previas a la partición y la supervisión judicial es claramente prescindible; apostar decididamente por la jurisdicción voluntaria hubiera sido positivo, limitando a lo sumo la intervención judicial a los supuestos en que se vean afectados menores $\mathrm{y}$, en su caso, en relación al eventual control posterior.

18 Circular FGE 6/2015, de 17 de noviembre de 2015, sobre aspectos civiles de la sustracción internacional de menores. 


\section{La tutela procesal (declarativa especial) del crédito.}

El último bloque de procesos especiales lo constituyen el monitorio ${ }^{19} \mathrm{y}$ el cambiario. ${ }^{20}$ Siendo el primero una novedad en el derecho español, ${ }^{21}$ no puede decirse lo mismo del segundo, presente hasta la LEC como juicio ejecutivo especial, transformado por ésta en proceso declarativo especial y sumario. ${ }^{22}$

Más que la materia como elemento determinante de las especialidades procesales, en este caso nos encontramos con una auténtica justificación procesal que no deriva del derecho sustantivo. Da igual la materia de que se trate, lo relevante es la protección del acreedor y de su crédito, ya sea sobre la base de un soporte documental que sustente una apariencia de la deuda, ya sea por la existencia de una letra, cheque o pagaré.

La introducción de la técnica monitoria venía siendo reclamada con insistencia por la doctrina procesal ${ }^{23}$ y se ha consolidado como un mecanismo de protección del crédito de enorme utilidad. Permite la articulación de instrumentos procesales de tutela del crédito sobre la base de la afirmación inicial de su existencia por el acreedor; ello es suficiente para requerir de pago al deudor y situarle ante la disyuntiva de pagar o negarse a ello, porque, al contrario de lo que sucede en los procesos declarativos ordinarios, su inactividad tiene la negativa consecuencia de dar lugar a la constitución de un título ejecutivo contra él. Si bien el primer objetivo del acreedor es cobrar, la finalidad que se consigue a través del monitorio es que la inactividad del deudor dé lugar a la constitución de un título ejecutivo. La estructura procesal a la que obedece se basa en la inversión de la

19 CALAMANDREI, P.: El procedimiento monitorio, Trad. Sentís Melendo. S. Editorial Bibliográfica Argentina, Buenos Aires, 1946. CORREA DELCASSO, J.P.: El proceso monitorio de la nueva Ley de Enjuiciamiento Civil. Marcial Pons, Barcelona, 2000.

20 ADÁN DOMENECH, F.: El nuevo proceso cambiario. J.M Bosch, Barcelona, 2002. GARBERÍ LLOBREGAT, J.: El juicio cambiario en la Ley de Enjuiciamiento Civil, $2^{\mathrm{a}}$ ed. Bosch, Barcelona, 2012. GUASCH FERNÁNDEZ, S.: El juicio cambiario. Atelier, Barcelona, 2006. RODRÍGUEZ MORÁN, M.A.: Los motivos de oposición en el juicio cambiario. Dijusa, Universidad Nebrija, 2007

21 Anticipada unos meses antes de la aprobación de la LEC por la reforma de Ley de Propiedad Horizontal (Ley 8/1999, de 6 de abril).

22 La naturaleza del proceso cambiario es una cuestión discutida; expongo mi opinión en ROCA MARTÍNEZ, J. $\mathrm{M}^{\mathrm{a}}$ : Tutela procesal del crédito. $3^{\mathrm{a}}$ ed. Ediciones de la Universidad de Oviedo (EDIUNO), Oviedo 2017. Págs. 97-98.

23 SERRA DOMÍNGUEZ, M.: Con anterioridad, la doctrina procesal más autorizada se pronunció en los trabajos recopilados bajo el título Corrección y actualización de la Ley de Enjuiciamiento Civil, Madrid, 1972-74 y con ocasión de los trabajos de la Sección especial de la Comisión General de Codificación para la reforma procesal, presidida por Almagro Nosete, publicados por el Ministerio de Justicia como Materiales para una reforma Procesal, Madrid, 1991. 
iniciativa del contradictorio, de manera que para evitar la creación del título ejecutivo el deudor se ve abocado a provocar el contradictorio. En cuando a la eficacia, con esta sencilla fórmula se logran plenos efectos de cosa juzgada, no solo ante una eventual oposición (contradictorio), sino también en los casos de creación del título ejecutivo por la inactividad del deudor. Finalidad, estructura y efectos hacen del monitorio, desde el punto de vista jurídico-procesal, un proceso especial, confirmando esta consideración su limitado objeto, circunscrito exclusivamente a reclamaciones de cantidad que reúnan determinados requisitos.

Por su parte, la letra de cambio ha gozado tradicionalmente de la protección que nuestro ordenamiento otorga a los títulos ejecutivos (1429 LEC 1881); sin embargo, la modificación operada en esta materia por la LEC ha dejado sin eficacia ejecutiva a la letra de cambio (pese a lo que dispone el artículo 66 Ley Cambiaria y del Cheque) pudiendo acudirse al proceso especial cambiario (819-827 LEC) cuya finalidad es la rápida constitución de un título ejecutivo. La doctrina se ha mostrado bastante crítica con la regulación del juicio cambiario, en especial se ha puesto de manifiesto la innecesaria distinción entre el monitorio y el cambiario y la inadecuada limitación de la eficacia de cosa juzgada del cambiario (Ramos Méndez, ${ }^{24}$ Bonet Navarro). ${ }^{25}$

Constatada la eficacia del monitorio, no resultaría descabellado reconducir a su tramitación, no solo la tutela procesal de la letra de cambio, sino también la de otros créditos procesales a favor de procuradores (34 LEC) y abogados (35 LEC). ${ }^{26}$

\section{Tutela declarativa especial fuera de la LEC}

La LO 6/2002, de 27 de junio, de Partidos Políticos (LOPP), regula un procedimiento judicial cuyo objeto es la disolución forzosa por ausencia de

$24 \quad$ RAMOS MÉNDEZ, Enjuiciamiento civil, ob. cit. Pág. 1645.

25 BONET NAVARRO, J.: Derecho Procesal Civil. En: Ortells Ramos, M. (dir. y coord.), $17^{\mathrm{a}}$ ed. Aranzadi, Navarra, 2018. Pág. 767.

26 En ambos casos, estamos ante instrumentos privilegiados de protección de créditos procesales y profesionales. Su naturaleza jurídica es bastante discutida; la sumariedad (ausencia de cosa juzgada) los distingue del monitorio; la audiencia del demandado con anterioridad a cualquier medida ejecutiva los separa de la ejecución. Así pues, su finalidad es la rápida constitución de un título ejecutivo que se producirá de manera casi automática y sin actividad declarativa si no hay oposición y de forma más compleja en caso de que el deudor se oponga. Se trata, en consecuencia, de una tutela declarativa especial, de carácter sumario (ROCA MARTÍNEZ, Tutela procesal del crédito, ob. cit. Pág. 118). 
estructura o funcionamiento democráticos o por realización de actividades que infrinjan los principios democráticos y valores constitucionales. ${ }^{27}$

Al contrario de la práctica habitual de remitir la tramitación a alguno de los procesos previsto en la LEC, en este caso se ha optado por establecer las reglas específicas (11 LOPP), careciendo todas ellas de una mínima justificación procesal, si exceptuamos la atribución competencial a la sala especial del TS prevista en el artículo 61 LOPJ (10.5 LOPP). ${ }^{28}$

\section{Dualidad de tutela declarativa ordinaria.}

\section{Ordinario y verbal como instrumentos de tutela declarativa es- pecial.}

La materia es utilizada también para justificar especialidades procesales relacionándola con la necesidad de rapidez: "Pero la materia no sólo se considera en esta Ley, como en la de 1881, factor predominante respecto de la cuantía, sino elemento de muy superior relevancia, como lógica consecuencia de la preocupación de esta Ley por la efectividad de la tutela judicial. Y es que esa efectividad reclama que por razón de la materia, con independencia de la evaluación dineraria del interés del asunto, se solvente con rapidez -con más rapidez que hasta ahora- gran número de casos y cuestiones" (EM LEC X). La distribución entre los dos instrumentos de tutela declarativa ordinarios se realiza en función de la materia y de la cuantía, si bien siempre con preferencia de la primera sobre la segunda. Aunque inicialmente los artículos 249 y 250 LEC se limitan a determinar

27 FERREIRO BAHAMONDE, X.: El proceso de disolución de partidos politicos. Iustel publicaciones, Madrid, 2008.

28 La demanda se presentará por escrito y acompañada de los documentos que acrediten la concurrencia de la ilegalidad alegada. La eventual adopción de medidas cautelares se sujeta al régimen general de la LEC, pudiendo solicitarse la suspensión cautelar de las actividades del partido. Se procederá al inmediato emplazamiento del Partido (o de los candidatos en el caso de agrupaciones electorales) para comparezcan en el plazo de ocho días; comparecidas o transcurrido el plazo se resolverá sobre la admisión de la demanda, pudiendo inadmitirse por falta de legitimación o representación, manifiesto incumplimiento de requisitos y manifiesta falta de fundamento; la inadmisión requiere el previo traslado a las partes para alegaciones en el plazo de diez días. Tras la admisión, el demandado dispone de veinte días para contestar por escrito; el periodo de prueba ha de ser solicitado por las partes o acordado por la Sala por estimarlo necesario y se desarrollará conforme a lo dispuesto en la LEC. Del conjunto de la prueba practicada se dará nuevamente vista a las partes para que formulen alegaciones por plazo sucesivo de veinte días, tras lo cual quedará visto para sentencia, que deberá dictarse en veinte días. La sentencia es firme y frente a ella no cabe recurso alguno (con independencia de lo dispuesto para el recurso de amparo). 
el procedimiento adecuado (ordinario o verbal), sus consecuencias van más allá y no se limitan a esa determinación, sino que dan lugar a numerosas especialidades, no solo en los aspectos procedimentales (actuaciones previas, diligencias preliminares, aportación de documentos, prueba, medidas cautelares, recursos), sino también en la estructura procesal introduciendo procedimientos sumarios (limitación de medios de ataque y defensa, del objeto y de la cosa juzgada).

Como ya adelanté al inicio, la dualidad de tutela declarativa ordinaria es algo habitual y obedece a la necesidad de disponer de un instrumento más sencillo y ágil para las reclamaciones de escasa cuantía y para las que, en razón de la materia, se presuma su sencillez o requieran mayor rapidez. El Código Procesal Civil Modelo para Iberoamérica propone esta dualidad y su influencia se ha visto plasmada en numerosas legislaciones procesales, como es el caso de España; aun sin mención en su exposición de motivos, resulta indudable que la LEC recoge la propuesta del Código Modelo.

\section{La aspiración de rapidez en otras materias como justificación de especialidades procesales. Los juicios rápidos.}

También relaciona la materia con la rapidez la Ley Orgánica 19/2003, de 23 de diciembre de modificación de la LOPJ, que introdujo en la DA $5^{\text {a }}$ LEC los denominados juicios rápidos civiles. ${ }^{29}$ No se trata de auténticos procedimientos especiales, sino de medidas de agilización sobre determinados procesos, tan llamativas mediáticamente, como inaplicadas en la práctica. ${ }^{30}$

Su especialidad descansaba en la creación de las denominadas Oficinas de Señalamiento Inmediato (OSI) como servicio común procesal con funciones de registro, reparto y señalamiento de vistas, comparecencias y actuaciones diversas. Prevista su aplicación exclusivamente a la relación

29 Castelló García, G. «Juicios rápidos en el proceso civil». En: Actualidad Jurídica Aranzadi, núm. 699/2006, parte Comentario [Aranzadi Instituciones, BIB 2006\77].

30 "Los mediáticamente conocidos como «juicios rápidos civiles» no son ningún tipo de procedimiento diferente a los previstos en la LEC. Aquella expresión, y la regulación de la disp. adic, $5^{\text {a }}$ significan una técnica de agilización de algunas clases de procedimientos civiles que no altera su régimen normativo, sino que actúa (o debe actuar) sobre los servicios judiciales que tienen encomendada la tramitación, mejorando sus medios (humanos y materiales) y su organización para conseguir una mayor eficiencia" (ORTELLS RAMOS, M.: Derecho Procesal Civil. 17ª ed. Aranzadi, Navarra, 2018 Pág. 469). 
de materias que la propia DA $5^{\mathrm{a}}$ especifica, ${ }^{31}$ la falta de voluntad política resultó determinante para que su desarrollo no se llevase a cabo.

\section{Especialización de los instrumentos de tutela declarativa ordinaria.}

La delimitación que realizan los artículos 249 y 250, aparte de fijar el ámbito del juicio ordinario y del juicio verbal, es aprovechada para introducir una categoría intermedia entre los instrumentos de tutela declarativa ordinarios y los especiales; tanto a través del juicio ordinario como del verbal se tramitan las cuestiones litigiosas que surjan dentro de sus respectivos ámbitos, sujetas a especialidades, en unos casos dispersas por la LEC y en otras incluidas en la correspondiente legislación sustantiva. Para su identificación se ha extendido la denominación procedimientos ordinarios $^{32}$ o comunes ${ }^{33}$ con especialidades, poniendo así de manifiesto que la estructura básica se corresponde con el ordinario o verbal, pero con particularidades.

\section{Procedimientos especiales tramitación a través del ordinario o del verbal en función de la cuantía}

Siendo lo habitual en los procedimientos especiales la remisión expresa a su tramitación a través del ordinario o el verbal, hay supuestos en que tal remisión no existe $\mathrm{y}$, por consiguiente, la tramitación se ha determinar en función de la cuantía. Así sucedía con la exigencia de responsabilidad civil a jueces y magistrados y con la declaración de nulidad de préstamos usurarios. En la actualidad subsiste para los supuestos de responsabilidad civil derivada de la utilización de vehículos a motor.

Aparte de la responsabilidad del Estado por el funcionamiento anormal de la Administración de Justicia, el derecho español se caracterizaba por la posibilidad de reclamar la responsabilidad civil directa de los jueces y magistrados, regulada en los artículos 297, y 411 a 413 LOPJ; en este sentido, la LEC 1881 regulaba un procedimiento especial para tales

31 Reclamaciones de cantidad que no excedan de $6.000 €$, desahucio por expiración del plazo o por falta de pago y reclamación de cantidades adeudadas, medidas cautelares en procesos sobre guarda y custodia o sobre alimentos, medidas provisionales o simultáneas en procesos de separación y divorcio y demandas de separación y divorcio de mutuo acuerdo o de un cónyuge con consentimiento del otro (DA $5^{\mathrm{a}} .2 \mathrm{LEC}$ ).

32 GIMENO SENDRA, Derecho Procesal Civil II, ob. cit. Pág. 359.

33 ORTELLS RAMOS, Derecho Procesal Civil, ob.cit. Pág. 471. 
reclamaciones. Aunque la LEC no reguló uno equivalente, sí incluía alguna especialidad ( $266.1^{\circ}$ LEC y 411 a 413 LOPJ) definitivamente eliminada por la LO 7/2015, de 21 de julio, que suprimió la responsabilidad civil de los Jueces y Magistrados.

La Ley de 23 de julio de 1908 de Represión de la Usura (Ley de Azcárate), incluía diversas especialidades procesales (2, 8, 12 y 13) para instar la nulidad de los contratos de préstamo por considerarlos usurarios que la LEC derogó (DD única.2.4\% ). Como única particularidad mantiene la LEC en el artículo 319.3 la no vinculación del tribunal a la fuerza probatoria de los documentos públicos.

Las DA primera y segunda de la LO 3/1989, regulaban el que en la práctica era conocido como «juicio verbal del automóvil». Se establecía la remisión expresa a los trámites del juicio verbal de todos los procesos civiles relativos a la indemnización de los daños y perjuicios ocasionados con motivo de la circulación de vehículos de motor, cualquiera que fuera su cuantía. La intención de la LEC era mantener el modelo de juicio verbal, por la Ley Orgánica que la acompañaba y que lo preveía no fue aprobada, razón por la que inicialmente se plantearon dos posturas contrapuestas sobre la vigencia o no de las DA de la LO 3/1989, resueltas definitivamente en favor de su derogación tácita. En definitiva, las demandas relativas a las indemnizaciones de los daños y perjuicios ocasionados con motivo de la circulación de vehículos de motor han de tramitarse por el juicio ordinario o verbal dependiendo de su cuantía. Las especialidades afectan a la competencia territorial (fuero imperativo en favor del tribunal del lugar en se produce el daño $-52.1 .9^{\circ}-$ ), a la exigencia de depósito para recurrir (449.3).

Más adelante se tratan las especialidades en materia de protección de consumidores que también tienen tramitación a través del ordinario o verbal en función de la cuantía, con alguna excepción que allí se explica (5.2.3.2).

\section{Procedimientos tramitados a través del juicio ordinario}

El juicio ordinario obedece al modelo de enjuiciamiento basado en una doble audiencia; la primera cumple función sanadora, de facilitación del debate, de delimitación del objeto y delimitación de la prueba; la segunda es la fase decisora o auténtico juicio, en la que se desarrolla la prueba y se formulan las conclusiones. En la distribución de materias, el legislador 
reserva el juicio ordinario para la tramitación de las demandas que considera que pueden revestir mayor complejidad.

\subsection{Protección jurisdiccional de derechos fundamentales y protec- ción del derecho al honor, intimidad y propia imagen}

Así como respecto a la constitucionalidad de las leyes, nuestro sistema ha optado decididamente por un control concentrado (Tribunal Constitucional), respecto a la protección de los derechos fundamentales se puede decir que ha instaurado una protección mixta (difusa y concentrada) en la que los tribunales ordinarios tienen la primera palabra y el Tribunal Constitucional la última. ${ }^{34}$ Se habla así de amparo ordinario y amparo constitucional.

La Constitución prevé un procedimiento especial de protección de los derechos fundamentales de carácter preferente (se refiere a la tramitación) y sumario (se refiere a la rapidez, como explica la Exposición de Motivos de la LEC); no obstante, el desarrollo de dicha previsión no se ha hecho. Venía siendo de aplicación la Ley 62/1978 (modificada por RDLeg. 342/1979, en cuanto a su ámbito), que remitía la tramitación al procedimiento incidental; derogados sus artículos 11 a 15 por la LEC, en la actualidad se hace al juicio ordinario con tramitación preferente y mínimas especialidades sobre legitimación activa, imposibilidad de ejecución provisional (salvo pronunciamientos puramente patrimoniales $-525.1 .1^{\circ}-$ ) y posibilidad de recurrir en casación (requisito previo, además, para acceder en amparo ante el TC).

Por su parte, la LO 1/1982, de 5 de mayo regula la protección del derecho al honor, a la intimidad personal y familiar y a la propia imagen (18.1 CE) frente a cualquier tipo de intromisión ilegítima (1 LO 1/1982). ${ }^{35}$

$34 \quad$ GIMENO SENDRA, Derecho Procesal Civil II, ob. cit. Pág. 359.

35 No me resisto a recordar la tortuosa relación que durante bastantes años han tenido el TC y el TS, con especial significación en el ámbito de la protección del derecho al honor. Casos muy llamativos y altamente mediáticos fueron ejemplo de los desencuentros entre ambos, en razón a la delimitación de las funciones que constitucionalmente tiene atribuidas. Quizá el asunto «Isabel Pantoja» sea el más conocido (STS 1a 1157/1996, de 31 diciembre, [RJ 1996\9226], STC $2^{\text {a }} 115 / 2000$, de 5 mayo [RTC 2000`115], STS $1^{\text {a }} 776 / 2000$, de 20 julio [RJ 2000\6184], STC $2^{\text {a }} 186 / 2001$, de 17 septiembre [RTC 2001\186] y STS $1^{\text {a }} 1064 / 2001$, de 5 noviembre [RJ 2002\677]. CILLERO DE CABO, P.: «La protección jurisdiccional del derecho al honor, a la intimidad personal y familiar y a la propia imagen: desencuentros entre el Tribunal Constitucional y el Tribunal Supremo». En: Revista Doctrinal Aranzadi CivilMercantil, núm. 15/2002, parte Doctrina, Aranzadi Instituciones, BIB 2002\2019; RAMOS 
Las particularidades en este caso se limitan a algunos aspectos del plazo de ejercicio de la acción y a la legitimación, tramitándose conforme a lo dispuesto para la protección general de los derechos fundamentales, incluido su carácter preferente.

\subsection{Procedimientos en materias mercantiles (86.ter.2 LOPJ)}

Aunque no es fácil sistematizar o agrupar los distintos procedimientos, ni establecer notas o características comunes entre ellos, lo cierto es que existen unas materias predominantemente mercantiles, cuya regulación en leyes especiales sustantivas incluye particularidades procesales; la LEC ha tratado de reducir tales especialidades al mínimo, derogando artículos, remitiendo el régimen general del juicio ordinario e incorporando a su contenido tales especialidades.

El apartado $3^{\circ}$ del artículo 249.1 LEC incluye en el ámbito del juicio ordinario las demandas sobre impugnación de acuerdos sociales adoptados por Juntas o Asambleas Generales o especiales de socios o de obligacionistas o por órganos colegiados de administración en entidades mercantiles y el apartado $4^{\circ}$, las demandas en materia de competencia desleal, defensa de la competencia, en aplicación de los artículos $81 \mathrm{y}$ 82 del Tratado de la Comunidad Europea o de los artículos 1 y 2 de la LDC, propiedad industrial, propiedad intelectual y publicidad, excepto que versen exclusivamente sobre reclamaciones de cantidad, en cuyo caso se tramitarán por el procedimiento que corresponda por la cuantía. Con la creación de los Juzgados de lo Mercantil la competencia objetiva les corresponde conforme a lo dispuesto en el artículo 86.ter LOPJ; en cuanto a la competencia territorial, se prevén diversas reglas especiales $\left(52.1 .10^{\circ}\right.$, $\left.11^{\circ}, 12^{\circ}, 13^{\circ}\right)$.

Las particularidades guardan relación directa con las respectivas materias, comenzando con la delimitación de las distintas tutelas que pueden instarse, afectando fundamentalmente a la legitimación, a las diligencias preliminares, a las medidas cautelares ${ }^{36}$ a la prueba y a los efectos de la sentencia.

MËNDEZ, F.: «La polémica Tribunal Constitucional y Tribunal Supremo». En: El mito de Sísifo y la ciencia procesal, Atelier, Barceona, 2004. Págs. 179-186.

36 ORTIZ PRADILLO, J.C.: Las medidas cautelares en los procesos mercantiles. Iustel, Madrid, 2006. 
En la regulación de las distintas formas societarias que pueden adoptar las entidades mercantiles se prevé la posibilidad de impugnar los acuerdos adoptados por las Juntas o Asambleas generales o especiales de socios, obligacionistas o por órganos colegiados de administración. ${ }^{37}$ Se regulan en RDLeg $1 / 2010$, de 2 de julio, que aprueba el texto refundido de la Ley de Sociedades de Capital (LSC), la Ley 27/1999, de 16 de julio, de Cooperativas (LC), Ley 44/2015, de 14 de octubre, de Sociedades Laborales y Participadas (LSLP) y la Ley 1/1994, de 11 de marzo, de Sociedades de Garantía Recíproca (LSGR).

El ámbito se extiende a la impugnación de acuerdos sociales adoptados por las Juntas o Asambleas Generales o especiales de socios, obligacionistas o por órganos colegiados de administración de entidades mercantiles. La competencia corresponde a los JMer (86.ter.2.a LOPJ) del lugar del domicilio social (carácter imperativo). La impugnación está sujeta a un plazo de caducidad de un año, excepto que se trate de acuerdos nulos por ser contrarios al orden público, en cuyo caso no hay plazo.

La legitimación para impugnar acuerdos contrarios al orden público se atribuye a cualquier socio, incluso si hubiera adquirido tal condición con posterioridad al acuerdo, administrador o tercero; para la impugnación de los demás acuerdos, los administradores y los terceros con interés legítimo, así como los socios que lo fueran al momento de la adopción del acuerdo que, además, representen individual o colectivamente un porcentaje del capital social del $1 \%$. La demanda debe dirigirse frente a la sociedad y cualquier socio que hubiera votado a favor del acuerdo puede intervenir para defender la validez del acuerdo; cuando el impugnante sea representante de la sociedad, está actuará conforme a lo previsto en sus estatutos y si éstos no previeran tal eventualidad, el Juez debe designar entre los socios que hubieran votado a favor, la persona que represente a la sociedad.

La tramitación se adapta al proceso ordinario, con las siguientes especialidades: acumulación de oficio de los procesos en que se impugnen acuerdos adoptados en la misma Junta o Asamblea o en una misma sesión de órgano colegiado de administración $\left(76.2 .2^{\circ}\right)$; se requieren ciertos porcentajes del capital social para poder solicitar la suspensión cautelar del acuerdo impugnado $\left(727.10^{\circ}\right)$; si el acuerdo estuviera inscrito o fuera inscribible en el Registro Mercantil, también deberá inscribirse un extracto

37 Redacción de Editorial Aranzadi, La impugnación de acuerdos sociales, Editorial Aranzadi, 2018. 
de la sentencia estimatoria (208 LSC); la cosa juzgada se extiende a todos los socios, aunque no hubieran litigado $\left(222.3^{\circ}\right)$

\section{a. Competencia desleal y publicidad}

La Ley 3/1991, de 10 de enero, de Competencia Desleal (LCD) contiene diversas disposiciones procesales que, a su vez, son de aplicación en materia de publicidad por la remisión expresa que realiza la Ley 34/1988, de 11 de noviembre, General de Publicidad (LGP).

A través de este proceso y en relación a actos o conductas que puedan incurrir en competencia desleal, se puede obtener la declaración de deslealtad y todas las consecuencias derivadas de tal declaración, como el cese de la conducta desleal, la prohibición de su realización o reiteración futura, la remoción de los efectos, la rectificación de informaciones engañosas, incorrectas o falsas, el resarcimiento de daños y perjuicios, así como las consecuencias derivadas del eventual enriquecimiento injusto (32 LCD).

La competencia corresponde a los JMerc del lugar del establecimiento del demandado o, en su defecto, de su domicilio o residencia en España; si los tiene en el extranjero, será competente el del lugar donde se haya realizado el acto de competencia desleal o donde se produzcan sus efectos, a elección del demandado (52.1.12). Las particularidades procesales guardan relación con la legitimación, ${ }^{38}$ las diligencias preliminares, ${ }^{39}$ la prueba ${ }^{40} \mathrm{y}$ las medidas cautelares. ${ }^{41}$

38 En la legitimación activa merece especial consideración la atribución a diversos organismos y asociaciones, conformando una amplia legitimación colectiva (33 LCD y 6 LGP). El ejercicio de las diversas acciones está sujeto a un plazo general de prescripción de un año desde que puedan ejercitarse y el legitimado conozca a la persona que realizó el acto o conducta desleal, con el límite máximo de 3 años desde su realización, si bien, tratándose de consumidores y usuarios, las acciones de cesación son imprescriptibles (56 LGDCU).

39 Para las diligencias preliminares, la LDC hace una remisión a la derogada Ley de Patentes (Ley 11/1986, de 20 de marzo) que habrá de actualizarse a los artículos 123 a 126 de la vigente Ley $24 / 2015$, de 24 de julio, de Patentes; en todo caso, se trata de un régimen específico que coexiste con la previsión general de la LEC, a la que complementa (256 a 263). VILLAR FUENTES, Isabel $\mathrm{M}^{\mathrm{a}}$ : Las diligencias preliminares de los procesos de propiedad industrial y competencia desleal. Tirant lo Blanc, Valencia, 2014.

40 Como especialidad probatoria, la carga de la prueba de la exactitud y veracidad de las indicaciones y manifestaciones realizadas y de los datos materiales que la publicidad exprese, corresponde al demandado (217.4).

41 En relación a las medidas cautelares, aparte de la previsión general que permite solicitar como tales el cese provisional en una actividad, la abstención temporal de llevar a 


\section{b. Defensa de la competencia}

La Ley 15/2007, de 3 de julio, para la defensa de la competencia (LDC) regula las infracciones en materia de Derecho de la Competencia, estableciendo procedimientos de naturaleza administrativa, revisables ante la jurisdicción contencioso-administrativa (47 LDC y 36 Ley 3/2013, de 4 de junio, de creación de la Comisión Nacional de los Mercados y la Competencia -LCNMC-). Al mismo tiempo, reconoce el derecho de cualquier persona física o jurídica perjudicada por una infracción del Derecho de la Competencia a reclamar al infractor y a obtener su pleno resarcimiento ante la jurisdicción civil ordinaria, comprendiendo el daño emergente y el lucro cesante, más los intereses (72 LDC). Las controversias derivadas de la aplicación de la LDC que estén atribuidas al orden jurisdiccional civil son competencia de los JMerc (86.ter.2.f LOPJ y DA Primera LDC). Las principales particularidades procesales guardan relación con las atribuciones de la Comisión Europea, la Comisión Nacional de la Competencia y los órganos equivalentes de las CCAA. ${ }^{42}$

\section{c. Propiedad industrial}

Los aspectos procesales de la propiedad industrial se encuentran en la Ley 24/2015, de 24 de julio, de patentes (LP), ya que tanto la Ley 17/2001, de 7 de diciembre, de marcas (LM) como la L 20/2003, de 7 de julio, de protección jurídica del diseño industrial (LPJDI), se limitan a realizar una remisión a la misma en todo aquello que no sea incompatible con sus propias respectivas disposiciones (DA Primera LM y DA Primera LPJDI).

$\mathrm{Al}$ contrario que otras leyes sustantivas, la LP ha optado por mantener fuera de la LEC la regulación de algunos aspectos procesales; así, del artículo 116 al 122 se regulan las disposiciones generales, del 123 al 126

cabo una conducta o la prohibición temporal de interrumpir o de cesar en la realización de una prestación que viniera llevándose a cabo, se prevé la posibilidad de que si se solicita el cese de una conducta ilícita, también se solicite que el Juez requiera los informes y ordene las investigaciones que el solicitante no pueda llevar a cabo y sean necesarias para resolver el caso concreto (732.2).

42 Tales entidades pueden intervenir en el proceso, por propia iniciativa o instancia del Juzgado, al objeto de desarrollar su función de colaboración con los órganos jurisdiccionales (15.bis LEC y 16 LDC); por otro lado, se les han de ir notificando las resoluciones que se dicten (demanda -404.3-, sentencia -212.3 y 434-, apelación -461.5-); además, puede suspenderse el plazo para dictar sentencia si existe tramitación administrativa ante cualquiera de tales órganos (465.6). 
las diligencias preliminares (de comprobación de hechos) ${ }^{43}$ del 127 al 137 las medidas cautelares ${ }^{44}$ y del 133 al 136 la solución extrajudicial de controversias.

Corresponde a los JMer la resolución de los litigios que se planteen como consecuencia del ejercicio de acciones relativas a la protección de invenciones industriales (LP), de signos distintivos (LM) y de la propiedad industrial del diseño (LPJDI) atribuidos a la jurisdicción civil, estando prevista una doble especialización. ${ }^{45} \mathrm{La}$ competencia territorial, si existe JMerc especializado, se establece en función del domicilio del demandado o, en su defecto, del lugar de residencia del representante autorizado en España para actuar en nombre del titular; de lo contrario, es competente cualquier JMerc especializado en la materia.

Frente a actos que violen los derechos protegidos en materia de propiedad industrial, el titular, el cotitular (80.2.d LP) y el solicitante de la inscripción (si llega a concederse -117.1 LP-) pueden ejercitar la acción de cesación o de prohibición de realización de tales actos (declarativa de condena), pudiendo acumular la indemnización de daños perjuicios, el embargo de objetos producidos o importados con violación de su derecho, de los medios destinados a tal producción, a atribución en propiedad de tales objetos y medios, la adopción de medidas para evitar que prosiga la vulneración y, si procede, la publicación de la sentencia (71 LP). Puede ejercitar las mismas acciones que el titular el licenciatario en exclusiva (salvo pacto), aunque no contra el concesionario; el licenciatario puede requerir al titular para que ejercite las acciones y si no lo hace en el plazo de tres meses, podrá ejercitarlas directamente. En todo caso, quien ejercite las acciones que corresponde al titular debe comunicárselo a éste, que podrá personarse como parte o como coadyuvante. La legitimación pasiva corresponde a quien realice los actos de violación

La acción de nulidad de una patente es pública, por lo que cualquier persona está legitimada para ejercitarla, excepto que la nulidad se base en que el titular no tuviera derecho a obtenerla, en cuyo caso solo puede instar

$43 \quad$ Vid. nota 38.

44 RUIZ MORENO, J.M : «La tutela cautelar del derecho de marca: la problemática de la doble regulación». En: IUSTEL, RGDP 35, 2015.

45 Por un lado, el CGPJ tiene la facultad de especializar a los JMer de la ciudad sede del TSJ de la CCAA, atribuyéndoles el conocimiento de estos asuntos en exclusiva; por otro, respecto a los litigios sobre marca comunitaria y dibujos y modelos comunitarios, la propia la LOPJ ha especializado a los JMerc de Alicante, como Juzgados de Marca Comunitaria y a una sección de la Audiencia Provincial de Alicante, como Tribunal de Marca Comunitaria. 
la nulidad quien esté legitimado para obtenerla (103.1 LP). La legitimación pasiva corresponde a quien aparezca como titular. La nulidad también puede plantearse como excepción o como reconvención por el demandado al que se atribuye la violación de la patente (120 LP).

La acción negatoria permite a cualquier interesado obtener del Juez, frente al titular, la declaración de que una actuación determinada no constituye vulneración de la patente; como requisito previo se exige haber requerido fehacientemente al titular y el transcurso de un mes sin respuesta de éste deja abierta la vía judicial. Esta acción no se puede ejercitar por quien haya sido demandado por infracción de la patente de que se trate, pero puede ejercitarse conjuntamente con la acción de nulidad.

En cuanto a la tramitación, se dispone que ha de ser como juicio ordinario, si bien se establecen algunas especialidades respecto a los plazos ${ }^{46}$ a la posibilidad de solicitar "diligencias de comprobación de hechos" ${ }^{47}$ y a la tutela cautelar. ${ }^{48}$ Las acciones civiles en materia de propiedad industrial prescriben a los cinco años desde que pudieron ejercitarse, excepto la acción de nulidad que puede ejercitarse durante toda la vida legal de la patente y durante los cinco años siguientes a su caducidad.

Por último, mencionar que la Oficina Española de Patentes y Marcas asume funciones de conciliación, mediación y arbitraje (133 a 136 LP).

\section{d. Propiedad intelectual}

La regulación sobre propiedad intelectual se recoge en el RDLeg. 1/1996, de 12 de abril, que aprueba el Texto Refundido sobre Propiedad Intelectual (LPI). ${ }^{49} \mathrm{Su}$ contenido ha sido afectado por la LEC, derogando (142) y modificando $(25.20,103$ o 143) algunos de sus artículos. Se trata

46 Para contestar a la demanda y, en su caso, a la reconvención, el plazo es de dos meses.

47 Tiene una finalidad esclarecedora y suponen una ampliación de las posibilidades del artículo 256 LEC que corresponde acordar al Juez, pudiendo recurrirse en apelación la denegación de las mismas; la ley es especialmente cuidadosa con la protección del secreto industrial y establece restricciones respecto a la información que puede ser facilitada al solicitante (124 LP).

$48 \quad$ Aquí las especialidades son mínimas y con reiteradas e innecesarias remisiones a la LEC, a cuyo régimen general bien podrían haberse incorporado; quizá lo más llamativo sea la posibilidad de adoptar medidas cautelares frente a los intermediarios de los que se sirve el supuesto infractor, aunque sus actos no constituyan en sí mismos infracción.

49 PALAO RAMÍREZ, F. PALAO MORENO, G. (Dir.): Comentarios a la Ley de Propiedad Intelectual. Tirant lo Blanc, Valencia, 2017. 
de una materia polémica y sujeta a permanentes modificaciones legales como consecuencia de la vertiginosa evolución de la tecnología y de la transferencia de información. Varias leyes han regulado esta materia con anterioridad a la vigente LPI (Ley de 1987, L 20/1992, 16/1993, 43/1994, $27 / 1995,28 / 1995$ ) y numerosas reformas han afectada a la LPI (hasta 12, siendo la última hasta la fecha la L 2/2019).

El ámbito de protección se extiende a las pretensiones de cese de la actividad ilícita, de indemnización por los daños materiales y morales sufridos, así como, en su caso, a la solicitud de publicación o difusión de la sentencia. La competencia corresponde al JMerc del lugar en que la infracción se haya cometido o existan indicios de su comisión o en que se encuentren ejemplares ilícitos, a elección del demandante $\left(52.1 .11^{\mathrm{a}}\right)$. La legitimación se atribuye, además de al titular (español o extranjero) del derecho lesionado, a las Entidades de Gestión autorizadas, conforme a lo dispuesto en sus estatutos (150 LPI).

El procedimiento aplicable es el juicio ordinario $\left(249.1 .4^{\circ}\right)$, que presenta especialidades en las diligencias preliminares $\left(256.1 .7^{\circ}\right.$ y $\left.8^{\circ}\right)$, en el deber de exhibición de documentos entre partes (328.3) y en las medidas cautelares; ${ }^{50}$ respecto a estas últimas, aunque se mantienen en vigor el artículo 141 LPI (intervención y depósito de ingresos, suspensión de actividades, secuestro de ejemplares, embargo de equipos, aparatos y materiales), se trata de medidas perfectamente prescindibles por cuanto tienen fácil encaje en las previstas en el artículo $727.7^{\mathrm{a}}, 8^{\mathrm{a}}$ y $9^{\mathrm{a}}$; por otro lado, también el art. 25.20 recoge la posibilidad de medidas cautelares (en supuestos de remuneración por copia privada) reconducibles al régimen general.

El artículo 158 LPI regula la Comisión de Propiedad Intelectual, ${ }^{51}$ adscrita al Ministerio de Cultura y Deporte, con funciones de mediación (194.1 LPI, colaborando en las negociaciones y formulando propuestas), así como en funciones de arbitraje (194.2 LPI, dando solución a los conflictos y fijando cantidades sustitutorias de las tarifas generales).

50 MONTESINOS GARCÍA, A.: «Las medidas cautelares en el ámbito de la propiedad intelectual». En: IUSTEL, RGDP, 40, 2016.

51 ARMENGOT VILLAPLANA, A.: «Las nuevas funciones de la Comisión de Propiedad Intelectual». En: IUSTEL, RGDP, 27, 2012. MONTESINOS GARCÍA, A.: «Últimas tendencias en la resolución alternativa de conflictos relativos a la propiedad intelectual: el centro de arbitraje y mediación de la OMPI». En: IUSTEL, RGDP, 30, 2013. 


\subsection{Tutela judicial en el ámbito del Derecho de Consumo}

El Derecho de Consumo ha experimentado un importante desarrollo durante las últimas tres o cuatro décadas, siendo un sector en el que el impulso de la UE ha sido determinante. La Directiva 93/13/CEE del Consejo, de 5 de abril de 1993 ha dado lugar a la Ley 7/1998, de 13 de abril, de Condiciones Generales de Contratación (LCGC), así como al RDLeg $1 / 2007$, de 16 de noviembre, por el que se aprueba el texto refundido de la Ley General para la Defensa de los Consumidores y Usuarios (LGDCU). La protección en este ámbito se extiende a los instrumentos procesales, siendo tan numerosas las particularidades previstas a lo largo de la LEC que podrían justificar su tratamiento específico a través de un proceso especial.

\section{a. Condiciones generales de contratación}

La LEC incorporó el contenido de los artículos de la LCGC que derogó $(9.3,14,15,18$ y 20$)$ y modificó otros $\left(12.2,3\right.$ y 4,16 y DA $\left.4^{\mathrm{a}}\right)$, a resultas de lo cual puede decirse que, si bien el régimen aplicable a las acciones individuales de no incorporación o de nulidad no ha sido prácticamente alterado por la LEC, manteniéndose las previsiones de los artículos 7 a 10 LGCGC, sí que lo ha sido el de las acciones colectivas de cesación, de retractación o declarativas de condiciones generales (12 LCGC). Por otro lado, la modificación que introduce en la DA $4^{\mathrm{a}}$ LCGC, extiende la aplicación de las medidas de protección previstas para consumidores y usuarios al ámbito de las Condiciones Generales, ya que las referencias a consumidores y usuarios de la LEC se entienden aplicables a todo adherente, aunque no sea consumidor o usuario y las referencias contenidas en la LEC a las asociaciones de consumidores y usuarios deben entenderse aplicables en los litigios en que se ejerciten acciones colectivas.

Para las acciones individuales de no incorporación o de nulidad la competencia corresponde a los JMer del domicilio del demandante y para las acciones colectivas de cesación, de retractación o declarativas de condiciones generales el del lugar donde el demandado tenga su establecimiento, a falta de este, el de su domicilio y si careciere de domicilio en el territorio español, el del lugar en que se hubiera realizado la adhesión (fuero de carácter imperativo, 52.1.14).

El procedimiento sigue los trámites del juicio ordinario, estando prevista la posibilidad de someter la cuestión con carácter previo al 
ejercicio de acciones colectivas al dictamen no vinculante del Registrador de Condiciones Generales (13 LCGC).

La legitimación para el ejercicio de las acciones colectivas se atribuye al MF y a las entidades previstas en el artículo 16 LCGC (asociaciones o corporaciones de empresarios, profesionales o agricultores, Cámaras de Comercio Industria y Navegación, colegios profesionales, asociaciones de consumidores, organismos o entidades administrativos competentes para la defensa de los consumidores; entidades de otros Estados miembros de la UE constituidas para la protección de los intereses colectivos y difusos de los consumidores); la demanda debe dirigirse contra el profesional que utilice o que recomiende públicamente la utilización de las condiciones generales que se reputan nulas (17 LCGC). Las acciones colectivas son imprescriptibles, si bien, cuando las condiciones generales hubieran sido inscritas en el Registro General de Condiciones Generales de Contratación, las acciones de cesación y de retractación prescriben a los cinco años.

\section{b. Consumidores y usuarios}

La general preocupación por la protección de los consumidores y usuarios se ha ido extendiéndose al ámbito procesal, siendo numerosas las disposiciones de la LEC que recogen especialidades, la mayoría referidas a la protección colectiva. ${ }^{52}$ Destacan la capacidad para ser parte de los grupos de consumidores y usuarios $\left(6.7^{\circ}\right)$; la capacidad procesal de quienes actúen en nombre del grupo frente a terceros $\left(7.7^{\circ}\right)$; la legitimación colectiva de las asociaciones de consumidores y usuarios (11.1 LEC) y de las asociaciones o corporaciones de empresarios, profesionales o agricultores, Cámaras de Comercio Industria y Navegación, colegios profesionales (DA 4 ${ }^{\mathrm{a}}$ LCGC), la legitimación institucional de Ios organismos o entidades administrativos competentes para la defensa de los consumidores, el Instituto Nacional de Consumo y los Institutos y organismos correspondientes de las CCAA y Corporaciones Locales (DA 4 ${ }^{\mathrm{a}}$ LCGC) y la legitimación oficial del MF

52 BONACHERA VILLEGAS, R.: Tutela procesal de los derechos e intereses de los consumidores. Tirant lo Blanc, Valencia, 2018. MARTÍN PASTOR, J.: «La tramitación de los procesos en los que se ejercitan acciones colectivas y acciones individuales para la tutela judicial de los consumidores y usuarios: previsiones legislativas, e interpretación y aplicación jurisprudencial». En: Jiménez Conde, F. dir.: Adaptación del Derecho Procesal español a la normativa europea y a su interpretación por los Tribunales, VVAA. Tirant lo Blanc, Valencia, 2018. Págs. 431-438. BELLIDO PENADÉS, R.: «La tutela civil de los intereses supraindividuales de los consumidores en el Código Modelo para Iberoamérica y en la LEC: Estudio comparado y propuestas de mejora». En: IUSTEL, RGDP, 37, 2015. 
(11.5), así como la legitimación difusa del propio grupo (11.2); la llamada al proceso de los consumidores perjudicados (15); la posibilidad de solicitar como diligencias preliminares la búsqueda de afectados o integrantes de un grupo $\left(256.1 \cdot 6^{\circ}\right)$.

El procedimiento (ordinario o verbal) se determinada conforme a la cuantía; no obstante, si por la materia es de aplicación alguna regla especial (por ejemplo, por tratarse de cuestiones sobre publicidad o sobre condiciones generales de contratación $-249.1 .4^{\circ}$ ), tiene preferencia. Se tramitan siempre a través del juicio verbal las demandas en que se ejerciten acciones de cesación en defensa de los intereses colectivos y difusos de consumidores y usuarios $\left(250.1 .12^{\circ}\right)$.

La sentencia está sujeta a las reglas establecidas en el artículo 221 LEC. $\mathrm{Si}$ es condenatoria, debe determinar individualmente los consumidores y usuarios beneficiados por la condena; cuando no sea posible la determinación individual, al objeto de facilitar la ejecución a instancia de las asociaciones, debe establecer los datos, características y requisitos necesarios para exigir el pago o instar la ejecución o intervenir en ella $\left(221.1 .1^{\circ}\right)$. Cuando declare la ilicitud de una conducta o la nulidad de una cláusula, la sentencia debe indicar si tal declaración ha de surtir efectos procesales respecto a quienes no hayan sido parte en el proceso $\left(221.1 .2^{\circ}\right)$. La estimación de una acción de cesación en defensa de intereses colectivos y difusos de los consumidores y usuarios puede dar lugar, si lo estima el Tribunal, a publicar total o parcialmente la sentencia (221.2).

\subsection{Procedimientos en materia de arrendamientos}

Hago una mínima referencia a los procedimientos en materia de arrendamientos para poner de manifiesto que la LEC, en su DD $2.6^{\circ}$ y $7^{\circ}$, ha derogado los artículos 38 a 40 de la L 29/1994, de 24 de noviembre, de Arrendamientos Urbanos (LAU) y los artículos 123 a 137 de la L 83/1980, de 31 de diciembre, de Arrendamientos Rústicos (LAR), manteniendo como particularidades, aparte de la competencia territorial improrrogable del juez del lugar en que esté sita la finca $\left(52.1 .7^{\circ}\right)$, la remisión al juicio ordinario de las demandas que versen sobre cualesquiera asuntos relativos a arrendamientos urbanos o rústicos de bienes inmuebles, salvo que se trate de reclamaciones de rentas o cantidades debidas por el arrendatario o del desahucio por falta de pago o por extinción del plazo de la relación arrendaticia $\left(249.1 .6^{\circ}\right)$; el apartado segundo en el artículo $250.1 .4^{\circ}$ (L $5 / 2018$ ) ha de interpretarse como otra excepción a la regla general. 


\subsection{Procedimientos de retracto}

El ejercicio de cualquier acción de retracto (comuneros, colindantes, enfitéutico, de censo de primeras cepas, de coherederos, en materia de arrendamientos rústicos y urbanos, etc.) está sujeto a las reglas del juicio ordinario $\left(249.1 .7^{\circ}\right)$. No hay normas especiales sobre competencia territorial, por lo que se determinará conforme a las reglas generales, con la única salvedad de que se trate de bienes inmuebles $\left(52.1 .1^{\circ}\right.$ y $\left.7^{\circ}\right)$. La legitimación activa corresponde al retrayente y la pasiva al adquirente primitivo y a los posteriores. Como especialidades procedimentales, a la demanda han de acompañarse los documentos que constituyan un principio de prueba y, en su caso, el que acredite la consignación cuando fuera exigida por la ley $\left(266.2^{\mathrm{a}}\right)$; la no presentación de los documentos exigidos provoca la inadmisión de la demanda, siendo recurrible el auto de inadmisión en apelación $\left(269.2,403.2,206.1 .2^{\circ}\right.$ y 455.1$)$.

\subsection{Procedimientos en materia de propiedad horizontal}

La Ley 49/1960, de 21 de julio, sobre Propiedad Horizontal (LPH), regula diversos procedimientos para cuya tramitación se siguen las reglas del juicio ordinario; como excepción, la reclamación de las cantidades adeudadas por el propietario en concepto de gastos generales o de dotación del fondo de reserva (9.e y $\mathrm{f} \mathrm{LPH}$ ) dispone de una modalidad de monitorio que se estudia más adelante (4.3).

Para el cese de actividades prohibidas en los estatutos, dañosas para la finca o contrarias a las disposiciones sobre actividades molestas, insalubres, nocivas, peligrosas o ilícitas, está legitimado el Presidente, previa autorización de la Junta, debiendo demandar al propietario y, en, al inquilino (litisconsorcio pasivo necesario), siendo necesario realizar un requerimiento fehaciente previo y acompañar a la demanda los documentos que acrediten dicho requerimiento, así como el acuerdo de la Junta.

Para la adopción de acuerdos cuando no pudieran lograrse por falta de la mayoría requerida en cada caso se regula un procedimiento de discutida naturaleza (jurisdicción voluntaria, jurisdicción de equidad, plenario especial rápido), de extrema sencillez, que permite a cualquier propietario, dentro del mes siguiente a la segunda junta, solicitar la declaración judicial del acuerdo que no pudo adoptarse, debiendo resolver en equidad y tras oír a los contradictores $(17.7 \mathrm{LPH})$. Este mismo trámite se puede seguir para la 
designación de Presidente, cuando no sea posible conforme a lo dispuesto en el artículo 13 LPH,

La impugnación de los acuerdos de la Junta de Propietarios cuando sean ilegales (contrarios a la ley o a los estatutos), lesivos (para los intereses de la propia comunidad en beneficio de uno o varios propietarios) o perjudiciales (para algún propietario) se regula en el artículo $18 \mathrm{LPH}$. La legitimación activa corresponde a los propietarios que hubiesen salvado su voto, a los ausentes y a los indebidamente privados de voto, que deberán estar el corriente del pago de la totalidad de las deudas vencidas con la Comunidad o proceder previamente a la consignación judicial de las mismas, salvo que se trate de acuerdos sobre la modificación o alteración de las cuotas. La pasiva corresponde al Presidente (en caso de ser impugnante, al vicepresidente o los votantes a favor). El plazo de ejercicio es de 3 meses, salvo que se trate de acuerdos contrarios a la ley o a los estatutos que será de 1 año.

\section{Procedimientos tramitados a través del juicio verbal}

\subsection{De carácter plenario}

\section{a. Precario}

El objeto del denominado juicio de precario tiene por objeto la plena recuperación de la posesión de una finca rústica o urbana, cedida en precario por el dueño, usufructuario o cualquier otra persona con derecho a poseer dicha finca. En la vigente LEC el precario ha perdido su carácter sumario, proporcionando una tutela plenaria, sin limitación de alegaciones y plena eficacia de cosa juzgada. La actual regulación planteó una duda inicial acerca de si el ámbito de este procedimiento solo permitía instar la recuperación de las fincas cedidas en precario (posesión tolerada) o si también incluía la recuperación de las fincas ocupadas sin cesión de ningún tipo (posesión u ocupación ilegítima); aunque la LEC se refiere a cesión en precario, el TS ha delimitado un concepto amplio aplicando el 250.1.2 ${ }^{\circ}$ a la recuperación tanto de la posesión simplemente tolerada, como de la ilegítima. La competencia corresponde con carácter imperativo a los JP del lugar donde esté sita la finca. En cuanto a la tramitación, se remite al juicio verbal $\left(250.1 \cdot 2^{\circ}\right)$.

La Ley 5/2018, de 11 de junio, de modificación de la LEC en relación a la ocupación ilegal de viviendas, introduce un supuesto específico de tutela 
sumaria de recuperación de la posesión frente a ocupaciones ilegítimas (apartado 1.4.2.2).

\section{b. Derecho de alimentos}

Para la reclamación de las cuestiones relacionadas con el derecho de alimentos (142 a $153 \mathrm{CC}$ ), la LEC contiene varias disposiciones que requieren un cierto esfuerzo interpretativo. Es bastante habitual que los pronunciamientos sobre alimentos se realicen en el marco de un proceso matrimonial (nulidad, separación o divorcio), dentro de las medidas definitivas (774 LEC, 91 a 93 CC), en cuyo caso, tal pretensión accesoria sigue la tramitación prevista para la principal, incluso cuando se trate de la modificación de las medidas ( 775 LEC). Las especialidades a las que ahora nos referimos son las que han de aplicarse cuando se solicitan alimentos debidos por disposición legal o por otro título de manera autónoma. Algunas imprecisiones legales hacen que se cuestione si existe una única tramitación. La previsión general establece la tramitación a través del juicio verbal de las demandas que soliciten alimentos debidos por disposición legal o por otro título $\left(250.1 .8^{\circ}\right)$; no obstante, el artículo $748.4^{\circ}$ prevé la aplicación de las disposiciones previstas para los procesos no dispositivos a los que versen exclusivamente sobre alimentos reclamados por un progenitor contra el otro en nombre de los hijos menores. Mientras algunos autores interpretan que todas las demandas de alimentos deben tramitarse conforme a las especialidades de los procesos no dispositivos (Gómez Colomer, ${ }^{53}$ Moreno Catena), ${ }^{54}$ otros entienden que hay dos procedimientos, el del artículo $748.4^{\circ}$ y el del artículo $250.1 .8^{\circ}$ (Asencio Mellado). ${ }^{55} \mathrm{Me}$ inclino por esta segunda interpretación y considero que el $748.4^{\circ}$ solo es de aplicación a los supuestos en que la reclamación de alimentos la realice un progenitor contra el otro, en nombre de los hijos menores; cualquier otra reclamación de alimentos debidos por disposición legal (por ejemplo, de ascendientes) o cualquier otro título (renta vitalicia, testamento) seguirá los trámites del juicio verbal $\left(250.1 .8^{\circ}\right)$ con las especialidades de los artículos $266.1^{\circ}, 439.5,608$ LEC. Se trata de un procedimiento de carácter plenario (EM XII) en el que la competencia se determina conforme a las reglas generales, correspondiendo al JPI (JFam) del domicilio del demandado y, si

53 GÓMEZ COLOMER, Derecho Jurisdiccional II, ob. cit. Pág. 760.

54 MORENO CATENA, V.: Derecho Procesal Civil. Parte Especial, $9^{\mathrm{a}}$ ed. Cortés Domínguez, V. Coaut., Tirant lo Blanc, Valencia, 2017. Págs. 95-98.

55 ASENCIO MELLADO, Derecho Procesal Civil, ob. cit. Págs. 526-528. 
no lo tuviere en el territorio nacional, al de su residencia habitual (50.1). La legitimación activa se atribuye al alimentista y la pasiva al alimentante; no será infrecuente que existan varios obligados (143 y $144 \mathrm{CC}$ ), planteándose el problema de su situación procesal, siendo determinante la naturaleza de la obligación. Mayoritariamente se viene considerando que se trata de una obligación mancomunada y divisible, por lo todos los obligados han de ser demandados (litisconsorcio pasivo necesario, SSTS 1a , 326/1994, de 12 de abril [RJ 1994\2789], 901/1996, de 5 de noviembre [RJ 1996\7905]), aunque tal exigencia desaparece cuando de manera manifiesta el alimentista no pueda asumir su obligación (insuficiencia de recursos, indigencia); no faltan, sin embargo, resoluciones que sostienen la inexistencia de litisconsorcio y admiten la posibilidad de demandar de manera separada $\mathrm{y}$ en procesos independientes a los distintos alimentistas (AAP Madrid, $10^{\mathrm{a}}, 215 / 2012$, de 19 de junio [JUR 2012\261807]). En todo caso, si la obligación está individualizada entre los distintos alimentistas, nada obliga a demandar conjuntamente a todos (p. ej. testamento en el que se identifican los alimentistas y sus respectivas obligaciones); por el contrario, siempre que no esté individualizada la obligación de cada alimentista, la situación será de litisconsorcio pasivo necesario.

Sus especialidades consisten en la necesidad de acompañar a la demanda el título en virtud del cual se piden los alimentos (266. ${ }^{\circ}$ y 439.5), no siendo de aplicación las limitaciones establecidas respecto a la inembargabilidad (608). De no acompañarse el título, la demanda se inadmite se inadmite por auto susceptible de apelación, con tramitación preferente (455.3).

\section{c. Derecho de rectificación}

La Ley Orgánica LO 2/1984, de 16 de marzo, sobre el derecho de rectificación, regula el procedimiento aplicable a las pretensiones que soliciten la condena a un medio de comunicación a publicar la rectificación de informaciones con hechos inexactos y perjudiciales.

Está legitimada toda persona natural o jurídica perjudicada por la difusión de una noticia inexacta, transmitiéndose a sus herederos. Para acudir a la vía judicial es preciso instar previamente la rectificación dirigiéndose al director del medio de comunicación, si bien no será necesario cuando se trate de medios de comunicación de titularidad pública. Si no se lleva a cabo la rectificación, puede accederse a la vía judicial mediante un escrito sin necesidad de intervención de abogado ni procurador. La competencia corresponde con carácter imperativo al JPI del 
domicilio del perjudicado o del lugar donde radique la dirección del medio de comunicación, a elección del demandante. La tramitación se realiza a través del juicio verbal $\left(250.1 .9^{\circ}\right)$, con alguna medida de aceleración; no es necesaria la intervención de abogado ni procurador (5 LODR); la demanda ha de ir acompañada de la justificación de la reclamación previa al director del medio de comunicación, pudiendo inadmitirse cuando resulte manifiestamente improcedente la rectificación solicitada (5 LODR). El juez (ahora será el LAJ) convocará la vista dentro de los siete días siguientes a la petición y podrá reclamar de oficio al demandado que remita o presente la información enjuiciada, su grabación o reproducción escrita. La sentencia se dictará en el mismo o al siguiente día del juicio y se limitará a denegar la rectificación o a ordenar su publicación o difusión en la forma y plazos previstos para la rectificación extraprocesal, contados desde la notificación de la sentencia. No cabe recurso frente a ninguna resolución, excepto apelación contra el auto de inadmisión por manifiesta improcedencia (8 LODR).

\section{d. Acción colectiva de cesación}

La Ley 39/2002, de 28 de octubre, de transposición al ordenamiento español de diversas directivas comunitarias en materia de protección de los intereses de los consumidores y usuarios, introdujo el apartado $12^{\circ}$ del artículo 250.1 LEC que se refiere al ejercicio de la acción de cesación en defensa de los intereses colectivos y difusos de los consumidores y usuario. Las materias en las que puede ejercitarse esta acción colectiva de cesación son múltiples y variadas: publicidad (6 LGP), condiciones generales de contratación (12 LCGC), cláusulas abusivas (53 y 54.1 LGDCU) y defensa de consumidores y usuarios (54.3 LGDCU), multipropiedad (21 L 4/2012), crédito al consumo (36 LCCC), propiedad intelectual (161.2 LPI). Para su tramitación se realiza una remisión expresa al juicio verbal.

La competencia objetiva corresponde a los JMer (86.ter.2.d LOPJ) y la territorial al del lugar donde el demandado tenga un establecimiento y, a falta de éste, el de su domicilio; si careciere de domicilio en territorio español, al del lugar del domicilio del actor $\left(52.1 .16^{\circ} \mathrm{LEC}\right)$.

Las particularidades en cuanto a la tramitación vienen referidas a las partes, a la sentencia, a las medidas cautelares y a la sentencia. Se reconoce la legitimación a las entidades habilitadas conforme a la normativa comunitaria europea para el ejercicio de la acción de cesación $\left(6.1 .8^{\circ} \mathrm{y}\right.$ 11.4 LEC), no existe obligación de llamar a los posibles afectados (15.4 
LEC), puede no exigirse caución si se solicitan medidas cautelares (728.3 LEC) y pueden imponerse apremios pecuniarios en caso de retraso en el cumplimiento de la sentencia (711.2 LEC).

\subsection{De carácter sumario}

\section{a. Desahucio}

Uno de los inconvenientes a los que se enfrentan los propietarios de viviendas a la hora de ofrecerlas en alquiler es la lentitud e ineficacia del Sistema Procesal para hacerefectivos sus derechos en caso de incumplimiento por parte del inquilino. El juicio de desahucio es el instrumento para instar judicialmente la resolución del contrato de arrendamiento y el desalojo de la vivienda por expiración del plazo o cuando el inquilino adeude rentas $\mathrm{u}$ otras cantidades al propietario, habiéndose ampliado su objeto al permitir la acumulación de la reclamación de las cantidades adeudadas. Aunque se suela utilizar la misma terminología, nada tiene que ver con otras formas de desalojo como son las ejecuciones hipotecarias, el juicio de precario (apartado 1.4.1.1) o la tutela sumaria de la posesión (apartado 1.4.2.2).

La legislación sustantiva contenía las especialidades procesales, tanto para los arrendamientos urbanos (38 a $40 \mathrm{LAU})$, como rústicos (123 a $137 \mathrm{LAR}$ ); la DD $2.6^{\circ}$ y $7^{\circ} \mathrm{LEC}$ derogó tales disposiciones, incorporando algunas especialidades que han ido aumentando con las sucesivas reformas en la materia (L 23/2003, LO 19/2003, L 13/2009, L 19/2009, L 37/2011 y L 4/2013).

La competencia territorial corresponde al tribunal del lugar en que esté situada la finca $\left(52.1 .7^{\circ}\right)$. La legitimación activa corresponde al dueño, usufructuario o cualquier persona con derecho a poseer la finca y a percibir, en su caso, las rentas y cantidades adeudadas; la pasiva a quien detente la posesión que se pretende recuperar y está obligado al pago.

En relación al procedimiento, la LEC remite al juicio verbal $\left(250.1 .1^{\circ}\right)$; sin embargo, las sucesivas reformas (en especial la Ley 37/2011) han introducido significativas especialidades, tratando de dotar de mayor agilidad y eficacia. Se viene afirmando que su actual estructura responde a la "técnica monitoria" (punto III del Preámbulo L 37/2011); como se explica más adelante (apartado 4.4), sin desconocer la similitud entre ambos en la primera fase (el requerimiento sitúa al demandado ante la posibilidad de pagar o dar razones), dos circunstancias distinguen al desahucio del 
monitorio: que su objeto no se limita a reclamaciones de cantidad y su naturaleza sumaria.

La demanda, además de los requisitos generales exigidos en el juicio verbal, debe indicar las circunstancias concurrentes que puedan permitir o no la enervación del desahucio (439.3); además, puede incluir el anuncio de condonación total o parcial de la deuda, condicionada al desalojo, así como la solicitud del lanzamiento en la fecha que el juzgado fije (437.3 LEC). Como excepción a la regla general, a la pretensión de desalojo puede acumularse la reclamación de las cantidades adeudadas, incluso contra el fiador o avalista solidario (en este caso, previo requerimiento $-437.4 .3^{\circ}$-). Por lo que se refiere a la cantidad, se permite incluir la reclamación de las rentas que se devenguen con posterioridad a la presentación de la demanda hasta la entrega de la posesión efectiva de la finca (220.2).

El demandado tiene la posibilidad de enervar la acción de desahucio de finca urbana por falta de pago pagando o consignando, judicial o notarialmente, la cantidad reclamada y las que adeude en el momento del pago, terminando el proceso por decreto del LAJ; no procede la enervación si ya se ha hecho con anterioridad (excepto que el cobro no hubiera tenido lugar por causas imputables al arrendado) o si el arrendador hubiera requerido fehacientemente de pago con al menos un mes de antelación. Si el demandante se opone a la enervación, se convoca a una vista (conforme al 443) tras la cual el Juez dictará sentencia declarando enervada la acción o acordando el desahucio, condenando al arrendatario al pago de las costas (22.4).

En caso de haber ofrecido la condonación condicionada al desalojo, su cumplimiento por el demandado es un allanamiento con efectos de transacción que será homologada por decreto del LAJ. En caso de que incumpla el desalojo, el LAJ dejará sin efecto el acuerdo con un nuevo decreto, procediéndose al lanzamiento sin más trámite y sin notificación al demandado, en la fecha fijada en la citación (si es posterior el plazo acordado) o en la que se señale en el decreto (21.3).

Con la finalidad de evitar las posibles dilaciones en la tramitación del reconocimiento del derecho de asistencia jurídica gratuita, su solicitud debe hacerse dentro de los tres días siguientes a la notificación de la demanda, ya que, en caso contrario, la falta de designación no supone la suspensión de la celebración del juicio (33.4).

$\mathrm{Al}$ objeto de facilitar las comunicaciones, si no se ha designado en el contrato de arrendamiento un domicilio a tal efecto, se considerará como 
tal a todos los efectos el de la vivienda o local arrendado (155.3) y si no fuere posible así la notificación, se procederá a fijar cédula de citación en el tablón de anuncios de la Oficina Judicial (164).

Admitida la demanda el LAJ realizará el requerimiento al demandado para que desaloje, pague o enerve la acción; o en otro caso comparezca y formule oposición, alegando sucintamente las razones por las que no debe en todo o en parte lo reclamado o las circunstancias de la enervación (440.3). El requerimiento debe expresar, además, el día y hora para la vista (debiendo mediar 10 días desde la citación sin exceder de 20) y para la práctica del lanzamiento, la indicación de la posibilidad de enervar la acción, si ello fuera procedente, la advertencia de que de no comparecer se declarará el desahucio sin más trámite, la citación para recibir la sentencia al sexto día del señalado para la celebración de la vista y la advertencia de que en caso de sentencia condenatoria que no se recurra, el lanzamiento se realizará el día señalado, sin necesidad de nueva notificación.

Si el demandado no atiende el requerimiento o no comparece para oponerse o allanarse, el LAJ dicta decreto dando por terminado el juicio $\mathrm{y}$ procediendo al lanzamiento en la fecha que se hubiera señalado. Si accede al desalojo, sin oponerse ni pagar, el LAJ lo hará constar y dictará decreto dando por terminado el juicio, dejando sin efecto la diligencia de lanzamiento, excepto que el demandado interese que se mantenga para dejar constancia del estado de la finca. En ambos supuestos, el decreto impondrá las costas al demandado e incluirá las rentas debidas y las que se devenguen desde la demanda hasta la entrega de la finca.

Si el demandado comparece y formula oposición, se celebrará la vista en la fecha señalada. Se trata de una oposición limitada a las razones por las que entiende que no debe en todo o en parte la cantidad reclamada y a las circunstancias relativas a la procedencia de la enervación. A pesar de que en los juicios verbales de naturaleza sumaria no cabe formular reconvención (438.2) y de la oposición en el desahucio está limitada en los términos expuestos, se viene admitiendo por algunas audiencias la compensación del importe de la fianza. Tal solución puede entenderse por razones de economía procesal, pero tiene difícil sustento legal; por un lado, la oposición limitada lo excluye (440.3), por otro, el procedimiento adecuado a las cuestiones arrendaticias es el juicio ordinario $\left(249.1 .6^{\circ}\right)$. La incomparecencia del demandado a la vista determinará la declaración del desahucio sin más trámite. 
La sentencia que ponga fin al juicio de desahucio no produce efectos de cosa juzgada (447.2) y los recursos frente a ella están sujetos a reglas especiales, exigiendo al demandado tener satisfechas las rentas vencidas, declarándose desierto cualquiera de los recursos si durante su tramitación dejare de pagar los plazos que venzan o los que deba adelantar (449.1, 2, 4 y 5 ).

\section{b. Tutela posesoria («interdictos»)}

La LEC regula la tutela sumaria de la posesión, aunque sin una regulación independiente como hacía con los interdictos su predecesora (1633 y ss. LEC 1881); tal denominación ha desaparecido de la LEC, pero tanto en la doctrina como en la jurisprudencia sigue siendo habitual su utilización. Así, al delimitar los supuestos que han de tramitarse a través del juicio verbal, la LEC recoge el interdicto de adquirir $\left(250.1 .3^{\circ}\right)$, de retener o recobrar $\left(250.1 .4^{\circ}\right)$, de obra nueva $\left(250.1 .5^{\circ}\right)$ y de obra ruinosa $\left(250.1 .6^{\circ}\right)$, caracterizados por la exclusión del efecto de cosa juzgada.

El interdicto de adquirir tiene por objeto poner en posesión de bienes a quien los hubiera adquirido por herencia $\left(250.1 .3^{\circ}\right)$. La competencia corresponde al JPI del lugar donde hubiera tenido su último domicilio el finado $\left(52.1 .4^{\circ}\right)$. La legitimación se atribuye a quien pretenda la posesión frente a quien se oponga a la posesión solicitada (no puede ejercitarse frente a quien posea los bienes a título de dueño o usufructuario). Con la demanda se debe acompañar el documento en que conste la sucesión y se incluirá relación de testigos que puedan declarar sobre la ausencia de poseedor a título de dueño o usufructuario $\left(266.3^{\circ}\right)$. Oídos los testigos, el Tribunal dictará auto otorgando o denegando la posesión solicitada; dicho auto habrá de publicarse (edictos, Boletín Oficial y periódicos) para que los interesados puedan comparecer en el plazo de cuarenta días y contestar a la demanda; si no comparece nadie, se dictará sentencia confirmando la posesión; si comparece alguien, se citará para la celebración de la vista (441.1).

El interdicto de retener y recobrar tiene por objeto mantener la posesión si se ve perturbada o recuperarla frente a un despojo $\left(250.1 .4^{\circ}\right)$. La legitimación se atribuye a quien sufra la perturbación o se vea despojado de su posesión, frente a quien lleve a cabo esa perturbación o despojo. La admisión de la demanda está sujeta al plazo de un año desde la perturbación o despojo de la posesión. 
El interdicto de obra nueva tiene por objeto la suspensión de una obra nueva que se supone perjudicial $\left(250.1 .5^{\circ}\right)$. Es competente el JPI del lugar en que esté sita la obra $\left(52.1 .1^{\circ}\right)$. La legitimación se atribuye a quien resulte perjudicado por la obra nueva, que debe demandar al dueño o al encargado. Admitida la demanda, el tribunal debe dirigir la orden de suspensión al dueño o encargado de la obra, que podrá prestar caución para continuarla o para realizar las obras indispensables para conservar lo ya edificado. También puede acordar el reconocimiento judicial, pericial o conjunto con anterioridad a la vista.

El interdicto de obra ruinosa tiene por objeto la demolición o derribo de una obra, edificio, árbol, columna o análogo en estado de ruina y que amenace daños $\left(250.1 .6^{\circ}\right)$. Ostenta legitimación activa quien se sienta amenazado y pasiva el titular o responsable del objeto ruinoso que amenaza daños.

Un supuesto particular de tutela sumaria de la posesión ha sido introducido por la Ley 5/2018, de 11 de junio, de modificación de la LEC en relación a la ocupación ilegal de viviendas; ${ }^{56}$ su artículo único introduce un párrafo segundo en el apartado $4^{\circ}$ (interdicto de recobrar) que permite pedir la inmediata recuperación de la plena posesión de una vivienda o parte de ella a la persona física propietaria o poseedora legítima por otro título, a las entidades sin ánimo de lucro con derecho a poseerla y a las entidades públicas propietarias o poseedoras legítimas de vivienda social. El legislador intenta dar así respuesta frente al movimiento "okupa", permitiendo el interdicto de recobrar durante el plazo de un año desde la ocupación. Como especialidades se establecen el plazo de ejercicio de un año y la posibilidad de demandar a los ignorados ocupantes de la vivienda.

\section{c. Protección de los derechos reales inscritos}

Se trata del procedimiento previsto y regulado en el artículo $41 \mathrm{LH} \mathrm{y}$ en los artículos 137 y 138 RH. Para su tramitación la LEC remite al juicio

56 RIZO GÓMEZ, B.: «El nuevo juicio posesorio de recuperación de la vivienda ocupada de manera ilícita». En: IUSTEL, RGDP, 47, 2019. PÉREZ DAUDÍ, V.: «Especialidades procesales del desalojo de la vivienda ocupada ilegalmente». En: IUSTEL, $R G D P, 46,2018$. SAN CRISTÓBAL REALES, S.: «Las acciones civiles frente a la ocupación ilegal de inmuebles tras la Ley 5/2018, de 11 de junio». En: IUSTEL, RGDP, 46, 2018. 
verbal $\left(250.1 .7^{\circ} \mathrm{LEC}\right)$ con las especialidades previstas en los artículos $439.2,440.2$ y 444.2 LEC. ${ }^{57}$

Se dirige a otorgar una especial protección de los derechos reales inscritos en el Registro de la Propiedad, frente a cualquier perturbación de terceros sin título inscrito. Tratándose de una acción sobre un bien inmueble la competencia territorial corresponde al JPI del lugar en que esté sito $\left(52 \cdot 1 \cdot 1^{\circ}\right)$. La legitimación activa se atribuye al titular de los derechos reales inscritos y la pasiva a quien perturbe o se oponga al ejercicio de tales derechos, sin disponer de título inscrito. La demanda debe indicar las medidas que se consideren necesarias para asegurar la eficacia de la sentencia que recayere y ha de ir acompañada de la certificación literal del Registro de la Propiedad que acredite la vigencia del asiento que legitima al demandante (439.2). En la citación para la vista se ha de apercibir al demandado de que tanto su incomparecencia como no prestar la caución que exija el tribunal determinarán el dictado de una sentencia acordando las actuaciones solicitadas por el actor (440.2); si comparece y presta la caución fijada, puede formular oposición fundada exclusivamente 1) en la falsedad de la certificación del Registro o en la omisión en ella de derechos o condiciones inscritas que desvirtúen la acción ejercitada, 2) en poseer el demandado la finca o disfrutar el derecho discutido por contrato u otra cualquier relación jurídica directa con el último titular o con titulares anteriores o en virtud de prescripción, siempre que ésta deba perjudicar al titular inscrito y 3) que la finca o el derecho se encuentren inscritos a favor del demandado y así lo justifique presentando certificación del Registro de la Propiedad acreditativa de la vigencia de la inscripción (444.2).

\section{d. Venta de bienes muebles a plazos, arrendamiento financiero y arrendamiento de bienes muebles}

En la sociedad actual han surgido nuevas formas de contratación con la finalidad de permitir el acceso a bienes y servicios facilitando el pago de manera fraccionada. El Sistema Procesal no es ajeno a esa evolución $\mathrm{y}$ ha recogido algunas especialidades, entre las que destacan las previstas en materia de venta a plazos de bienes muebles, de arrendamiento financiero y de arrendamiento de bienes muebles. En tales casos, sobre la base de la inscripción registral y de la existencia de modelos oficiales de

$57 \quad$ CALDERÓN CUADRADO, $\mathrm{M}^{\mathrm{a}} \mathrm{P}$.: Tutela de los derechos reales inscritos. Tirant lo Blanc, Valencia, 2018. También da noticia urgente de la tutela sumaria frente a ocupaciones ilegales (pp. 224-229) 
contrato, se prevé un juicio verbal sumario dirigido a obtener una rápida sentencia que permita al acreedor cobrar a través de la ejecución sobre los bienes financiados o adquiridos a plazos $\left(250.1 .10^{\circ}\right)$ o le permita la resolución del contrato y la recuperación del bien a través de su inmediata entrega $\left(250.1 .11^{\circ}\right)$. La naturaleza sumaria deriva de la limitación de los medios de ataque y defensa, que determina que su objeto se circunscriba exclusivamente a tales posibilidades de alegación, así como a la limitación de la eficacia de cosa juzgada.

El acreedor (vendedor o arrendador) dispone de los instrumentos procesales de protección de su crédito previstos en la LEC, con los requisitos específicos de cada uno. Al vendedor a plazos, la LVPBM le reconoce la opción de reclamar el pago o de resolver el contrato y recuperar el bien, cuando el comprador demore el pago de dos plazos o del último de ellos (10 LVPBM); al arrendador solo le reconoce la posibilidad de resolución y recuperación del bien. El ejercicio de tales acciones puede hacerse a través del juicio declarativo que corresponda por la cuantía; la reclamación de las cantidades impagadas se puede realizar a través del monitorio, si dispone de documento apto para ello (812), y de la ejecución si dispone de título ejecutivo no judicial $\left(517.2 .4^{\circ}\right.$ y $\left.5^{\circ}\right)$. Aparte de ello, cuenta con el juicio verbal de carácter sumario previsto en el artículo $250.1 .10^{\circ}$ y $11^{\circ}$, con las especialidades previstas en los artículos 441.4, 444.3, 447.2 y 634.3 LEC.

Como requisito formal se exige que el contrato esté formalizado en el modelo oficial y conste inscrito en el Registro de Venta a Plazos de Bienes Muebles. Con carácter previo es necesario realizar un requerimiento de pago al deudor a través de fedatario público, expresando la cantidad total reclamada y la causa del vencimiento de la obligación, con apercibimiento al deudor de que, en el supuesto de no atender al pago de la obligación, se procederá contra los bienes adquiridos a plazos. Salvo pacto en contrario, la suma líquida exigible en caso de ejecución será la especificada en la certificación expedida por el acreedor, siempre que se acredite, por fedatario público, haberse practicado aquella liquidación en la forma pactada por las partes en el contrato y que el saldo coincide con el que aparece en la cuenta abierta al deudor. El deudor, dentro de los tres días hábiles siguientes a aquel en que sea requerido, deberá pagar la cantidad exigida o entregar la posesión de los bienes al acreedor o a la persona que éste hubiera designado en el requerimiento. Si el deudor no pagase, pero voluntariamente hiciera entrega de los bienes adquiridos a plazos, se procederá a su enajenación 
en pública subasta, con intervención de Notario o Corredor de Comercio colegiado, según sus respectivas competencias (16 LVPBM).

Salvo que resulte de aplicación alguno de los fueros imperativos del artículo 52.1 LEC, el demandante puede optar entre el JPI del domicilio del comprador o arrendatario y el que resulte de las reglas generales de los artículos 50 y 51 (52.2). La demanda ha de ir acompañada de la acreditación del requerimiento previo y de la certificación de la inscripción del contrato en el Registro si se tratase de bienes susceptibles de inscripción (439.4). Admitida la demanda, en el caso del apartado $10^{\circ}$ (ejecución), el tribunal acordará de oficio la exhibición de los bienes, bajo apercibimiento de incurrir en desobediencia a la autoridad judicial, así como su inmediato embargo preventivo y depósito, y en el caso del apartado $11^{\circ}$ (entrega), el tribunal ordenará el depósito del bien cuya entrega se reclame, en ambos casos sin exigir caución al demandante, ni admitir oposición ni solicitudes de modificación ni sustitución al demandado. El LAJ procederá a citar al demandado por cinco días para que se persone en las actuaciones, por medio de procurador, al objeto de oponerse (contestar) a la demanda (441.4), limitándose sus alegaciones a la falta de jurisdicción o de competencia del tribunal, al pago acreditado documentalmente, a la inexistencia o falta de validez de su consentimiento, incluida la falsedad de la firma, y a la falsedad del documento en que aparezca formalizado el contrato (444.3). Formulada oposición (contestada la demanda), el LAJ convocará a las partes a la vista; si el demandado no comparece, no mantiene su oposición o esta no se ajusta a los motivos admitidos, se dictará sentencia estimatoria de la demanda, contra la que no cabe recurso, imponiendo además al demandado una multa de hasta la quinta parte del valor de la reclamación, con un mínimo de ciento ochenta euros.

\section{Consideraciones finales}

A lo largo de este trabajo he tratado de realizar una exposición ordenada de los distintos instrumentos de tutela declarativa especial o privilegiada presentes en el Sistema Procesal español. El resultado es desalentador. Con más o menos especialidades se pueden contar: cinco en capacidad, dos en filiación, cuatro más uno en matrimonio, nueve en menores, dos en división judicial de patrimonios, dos más dos en tutela del crédito; tres de tramitación según la cuantía, catorce de tramitación a través del juicio ordinario y a través del verbal cuatro plenarios y ocho sumarios. A ello han de añadirse los incidentes (387-393), la provisión de fondos (28 y 342.3), 
la cuenta jurada (34) o la reclamación de honorarios (35). Por increíble que parezca, se cuentan más de media centena lo cual es absolutamente exagerado.

¿Está justificada tanta especialidad? ¿Necesidad o impericia legislativa? Incuria del legislador ${ }^{58}$, pastoreo furtivo ${ }^{59}$, oportunismo electoralista...; lo cierto es que el procesalismo no suele ser llamado a la tarea legislativa y, cuando es llamado, se le hace poco caso o se organiza en camarillas, no siempre abiertas al espíritu crítico, débiles ante la tentación de trasladar a los textos legales concepciones doctrinales propias $^{60}$.

Por desgracia estamos acostumbrados a la ausencia de planificación, a la carencia de sistemática y a los impulsos legislativos ocurrentes. Pero ¿hay margen de mejora? Entiendo que sí. En primer lugar, porque aun reconociendo particularidades (concesiones al principio de necesidad, estructura monitoria, sumariedad), no se pueden perder de vista unos principios, un esquema y una estructura común básica ${ }^{61}$; en segundo lugar, porque encauzar el desbordamiento, aunque exija esfuerzo, es posible. Sugiero para ello las siguientes pautas.

La simplificación en los procesos especiales podría mejorarse apostando decididamente por la jurisdicción voluntaria. Las separaciones y divorcios de mutuo acuerdo, la división judicial de patrimonios o determinadas autorizaciones, pueden desaparecer de la LEC y tener mejor acomodo en la LJV. La potenciación del monitorio también puede contribuir a la simplificación, no solo asumiendo la tramitación de la reclamación de letras, pagarés o cheques, sino también trasladando a su ámbito la reclamación de la cuenta del procurador y de los honorarios de abogado.

En los procedimientos especiales, las particularidades derivadas del derecho sustantivo requieren extremar la prudencia para valorar la conveniencia de su regulación. Su incorporación a la LEC no parece en todos los casos la solución más adecuada porque genera unos extensos y

$58 \quad$ RAMOS MÉNDEZ, Enjuiciamiento civil, T.II, ob. cit. Pág. 1542.

59 VÁZQUEZ SOTELO, J.L.: «Discrecionalidad y derecho procesal». En: Justicia, 1995, III-IV. Pág. 52

60 Es muy ilustrativa la lectura del trabajo de VÁZQUEZ SOTELO, J.L.: «"Objeto actual" y "objeto virtual” en el proceso civil español». En: RDProc., 2009. Págs. 997-1045.

61 "El hecho de que exista esta dispersión legislativa no debe empero hacernos perder de vista un dato fundamental: en el fondo, se trata de meras variantes del modelo de juicio, por el que, en las cuestiones fundamentales no puede andarse con veleidades. Las soluciones tienen que ser homogéneas en todos lo casos, por razones de pura lógica" (RAMOS MÉNDEZ, Enjuiciamiento civil, I, ob.cit. Pág. 1540. 
farragosos artículos (52, 256 o 727). La delimitación del ámbito objetivo de los procedimientos especiales (las distintas clases de tutela que se pueden solicitar) tiene una adecuada ubicación en las correspondientes leyes especiales; su relación directa con la legitimación aconseja la misma solución para su regulación y, de hecho, así se hace (con las excepciones de los artículos 11 y 11 bis). Entonces, si para la legitimación sirve la fórmula del artículo 10 ("se exceptúan los casos en que por ley se atribuya legitimación a persona distinta del titular") no se comprende por qué para las diligencias preliminares no se puede hacer una remisión parecida a las leyes especiales y menos aún por qué estando prevista tal remisión en la regulación de las medidas cautelares, el artículo 727 incluye diez apartados, casi todos ellos previstos para procedimientos especiales.

Las reglas sobre competencia requieren una profunda revisión para adaptarlas a un proceso civil moderno y ajustado a las nuevas tecnologías; superar de una vez la tradición es prioritario y saltarse los fueros generales debe ser absolutamente excepcional. Hay que reconocer, no obstante, que la verdadera actualización de la organización judicial española pasa necesariamente por una nueva Ley de Planta y Demarcación Judicial; sin ella, la actualización de las reglas de competencia territorial no sería más que un brindis al sol.

Por lo que se refiere a los procedimientos denominados sumarios, sujustificación histórica pueda haber perdido consistencia y, en todo caso, no debe caerse en el abuso. Solo la necesidad de una tutela urgente justifica su existencia cuando a través de una tutela declarativa, acompañada de eficaces medidas cautelares no pueda obtenerse el mismo resultado. Ya he hecho referencia a la conveniencia de superar la sumariedad para el cambiario, la cuenta jurada y la reclamación de honorarios, reconduciendo su tramitación al monitorio. La utilización de instrumentos procesales carentes de efecto de cosa juzgada, podría ser un derroche innecesario; después de más de veinte siglos, quizá convendría plantearse la utilidad real de la tutela sumaria de la posesión y si no sería suficiente con un eficaz y ágil sistema de tutela cautelar. 


\section{Bibliografía.}

ADÁN DOMENECH, F.: El nuevo proceso cambiario. J.M Bosch, Barcelona, 2002.

Almagro nosete, J.: Instituciones de Derecho Procesal. Proceso Civil, (Tomé Paule, J. Coaut.), $2^{\text {a }}$ ed., Editorial Trivium, S.A., Madrid, 1994.

ARANZADI (redacción de), La imugnación de acuerdos sociales, Editorial Aranzadi, 2018.

ARMENGOT VILLAPLANA, A.: «Las nuevas funciones de la Comisión de Propiedad Intelectual» En: IUSTEL, RGDP 27, 2012.

ASENCIO MELladO, J. Ma: Derecho Procesal Civil, $3^{\text {a }}$ ed. Tirant lo Blanc. Valencia, 2015.

BELLIDO PENADÉS, R.: «La tutela civil de los intereses supraindividuales de los consumidores en el Código Modelo para Iberoamérica y en la LEC: Estudio comparado y propuestas de mejora». En: IUSTEL, RGDP 37, 2015.

BONACHERA VILLEGAS, R.: Tutela procesal de los derechos e intereses de los consumidores. Tirant lo Blanc, Valencia, 2018.

CALAMANDREI, P.: El procedimiento monitorio, Trad. Sentís Melendo, S. Editorial Bibliográfica Argentina, Buenos Aires, 1946.

CALDERÓN CUADRADO, $\mathrm{M}^{\mathrm{a}}$ P.: Tutela de los derechos reales inscritos, Tirant lo Blanc, Valencia, 2018.

CASTELLÓ GARCÍA, G.: «Juicios rápidos en el proceso civil». En: Actualidad Jurídica Aranzadi, núm. 699/2006 parte Comentario [Aranzadi Instituciones, BIB 2006\77].

CILLERO DE CABO, P.: «La protección jurisdiccional del derecho al honor, a la intimidad personal y familiar y a la propia imagen: desencuentros entre el Tribunal Constitucional y el Tribunal Supremo». En: Revista Doctrinal Aranzadi Civil-Mercantil, núm. 15/2002 parte Doctrina, Aranzadi Instituciones, BIB 2002, 2019.

CORREA DELCASSO, J.P.: El proceso monitorio de la nueva Ley de Enjuiciamiento Civil. Marcial Pons, Barcelona, 2000. 
DE LA OLIVA SANTOS, A, DÍEZ-PICAZO GIMÉNEZ, I. VEGA TORRES, J.: Derecho Procesal Civil. Ejecución forzosa. Procesos especiales, $3^{\mathrm{a}}$ ed., Editorial universitaria Ramón Areces, Madrid, 2005.

FERREIRO BAHAMONDE, X.: El proceso de disolución de partidos políticos, Iustel publicaciones, Madrid, 2008.

GARBERÍ LLOBREGAT, J.: El juicio cambiario en la Ley de Enjuiciamiento Civil, $2^{\mathrm{a}}$ ed. Bosch, Barcelona, 2012.

GIMENO SENDRA, V.: Derecho Procesal Civil II. Los procesos especiales, $3^{\mathrm{a}}$ ed. Colex, Madrid, 2010.

GUASCH FERNÁNDEZ, S.: El juicio cambiario. Atelier, Barcelona, 2006.

GUASP Delgado, J.: Derecho Procesal Civil, Tomo segundo, Parte especial, $3^{\mathrm{a}}$ ed. Instituto de Estudios Políticos, Madrid, 1968.

MARTÍN PASTOR, J.: «La tramitación de los procesos en los que se ejercitan acciones colectivas y acciones individuales para la tutela judicial de los consumidores y usuarios: previsiones legislativas, e interpretación y aplicación jurisprudencial». En: Adaptación del Derecho Procesal español a la normativa europea y a su interpretación por los Tribunales, VVAA, Jiménez Conde, F. dir., Tirant lo Blanc, Valencia, 2018.

MONTERO AROCA, J.: Derecho Jurisdiccional II, Proceso Civil, VVAA, $26^{\mathrm{a}}$ ed. Tirant lo Blanc, Valencia, 2018, biblioteca tirant on line.

MONTESINOS GARCÍA, A.: «Las medidas cautelares en el ámbito de la propiedad intelectual». En: IUSTEL, RGDP 40, 2016.

MONTESINOS GARCÍA, A. «Últimas tendencias en la resolución alternativa de conflictos relativos a la propiedad intelectual: el centro de arbitraje y mediación de la OMPI». En: IUSTEL, RGDP 30, 2013.

MOREnO CATEnA, V. Derecho Procesal Civil. Parte Especial, 9a ed. Cortés Domínguez, V. Coaut., Tirant lo Blanc, Valencia, 2017.

ORTELLS RAMOS, M. Derecho Procesal Civil. $17^{\mathrm{a}}$ ed. Aranzadi, Navarra, 2018.

ORTIZ PRADILLO, J.C.: Las medidas cautelares en los procesos mercantiles. Iustel, Madrid, 2006. 
PALAO RAMÍREZ, F. PALAO MORENO, G. (Dir.): Comentarios a la Ley de Propiedad Intelectual. Tirant lo Blanc, Valencia, 2017.

PÉREZ DAUDÍ, V.: «Especialidades procesales del desalojo de la vivienda ocupada ilegalmente». En: IUSTEL, RGDP 46, 2018.

PICATOSTE BOBILLO, J. y SEOANE SPIEGELBERG, J.L. (coord.): Procesos especiales dispositivos por razón de la materia en la Ley de Enjuiciamiento Civil. Bosch, 2013.

RAMOS MÉNDEZ, F.: Enjuiciamiento Civil. Cómo gestinar los litigios civiles. T.II, Atelier, Barcelona, 2008.

RAMOS MËNDEZ, F.: «La polémica Tribunal Constitucional y Tribunal Supremo». En: El mito de Sísifo y la ciencia procesal. Atelier, Barcelona, 2004. Págs. 179-186.

RIZO GÓMEZ, B.: «El nuevo juicio posesorio de recuperación de la vivienda ocupada de manera ilícita». En: IUSTEL, RGDP 47, 2019.

ROCA MARTÍNEZ, J.Ma: «El Código Orgánico General de Procesos del Ecuador». En: García Falconí, R. y Pérez-Cruz Martín, A.J., dirs. y coords.: Código Orgánico General de Procesos comentado, VVAA. T.I. Latitud Cero editores, Quito, 2018.

ROCA MARTÍNEZ, J.M a: Tutela procesal del crédito. Ediciones de la Universidad de Oviedo (EDIUNO), Oviedo, $3^{\mathrm{a}}$ ed. 2017.

RODRÍGUEZ MORÁN, M.A.: Los motivos de oposición en el juicio cambiario. Dijusa, Universidad Nebrija, 2007.

RUIZ MORENO, J.M : «La tutela cautelar del derecho de marca: la problemática de la doble regulación». En: IUSTEL, RGDP 35, 2015.

SAN CRISTÓBAL REALES, S.: «Las acciones civiles frente a la ocupación ilegal de inmuebles tras la Ley 5/2018, de 11 de junio». En: IUSTEL, RGDP 46, 2018.

VÁZQUEZ SOTELO, J.L.: «Discrecionalidad y derecho procesal», Justicia, 1995, III-IV. Págs. 51-61.

VÁZQUEZ SOTELO, J.L.: «"Objeto actual” y "objeto virtual” en el proceso civil español». En: RDProc. 2009. Págs. 997-1045. 
